\title{
\&EPA
}

\section{Decision Series}

\section{A Small Oil Spill at West Falmouth $\Sigma$}

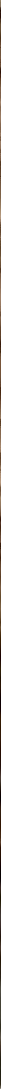




\section{The Energy/ Environment R\&D Decision Series}

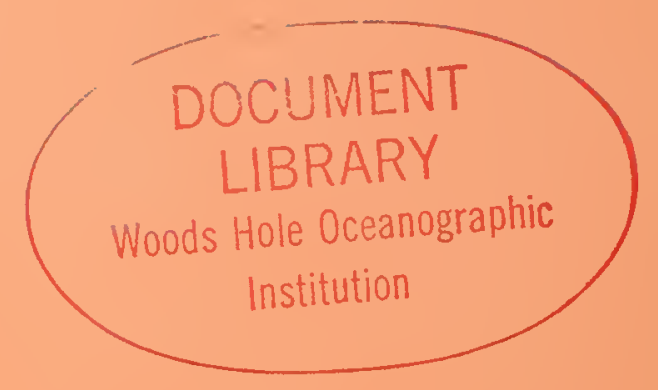

Some of the most basic problems facing our society today involve the use of our energy resources and the effects of this usage on our environment. These problems affect everyone, and everyone has an interest in their resolution. But the technical aspects of these problems make it difficult for a major portion of the interested public to understand and participate in the decision-making process. This volume contributes to the bridging of this information gap.

The Energy/Environment RGD Decision Series was inaugurated late in 1976. The series presents, in an easily understood and informative manner, selected key issues and findings of the Federal Interagency Energy/Environment Research and Development Program, which was initiated in fiscal year 1975 . Planned and coordinated by the Environmental Protection Agency (EPA), the Interagency Program sponsors more than 1,000 research projects ranging from the analysis of health and environmental effects of energy systems to the development of pollution control technologies.

If you have any comments, please write to Editor, RD-681, US EPA, Washington, D.C. 20460. This document is available through the National Technical Information Service, Springfield, Virginia 22161. Mention of trade names and commercial products herein does not constitute EPA endorsement or recommendation for use.

Editor: Francine Sakin Jacoff

Text: Dr. William Conner Technical Review:

Dr. Paul Lefcourt, Environmental Protection Agency

Dr. Donald Rhoads, Yale University

Dr. Howard Sanders, Woods Hole Oceanographic Institution

Graphics: Craig R. Keith;

Vincent Maiello 


\section{A Small Oil Spill at West Falmouth}

Preface .................... 3

Oil Pellution in the Occan .......... 4

The West Falmouth Spill . . . . . . . . 8

Tracing Spilled Oil . . . . . . . . . . . . 10

Effects of Spilled Oil . . . . . . . . . . . 16

Implications of West Falmouth . . . . 24 


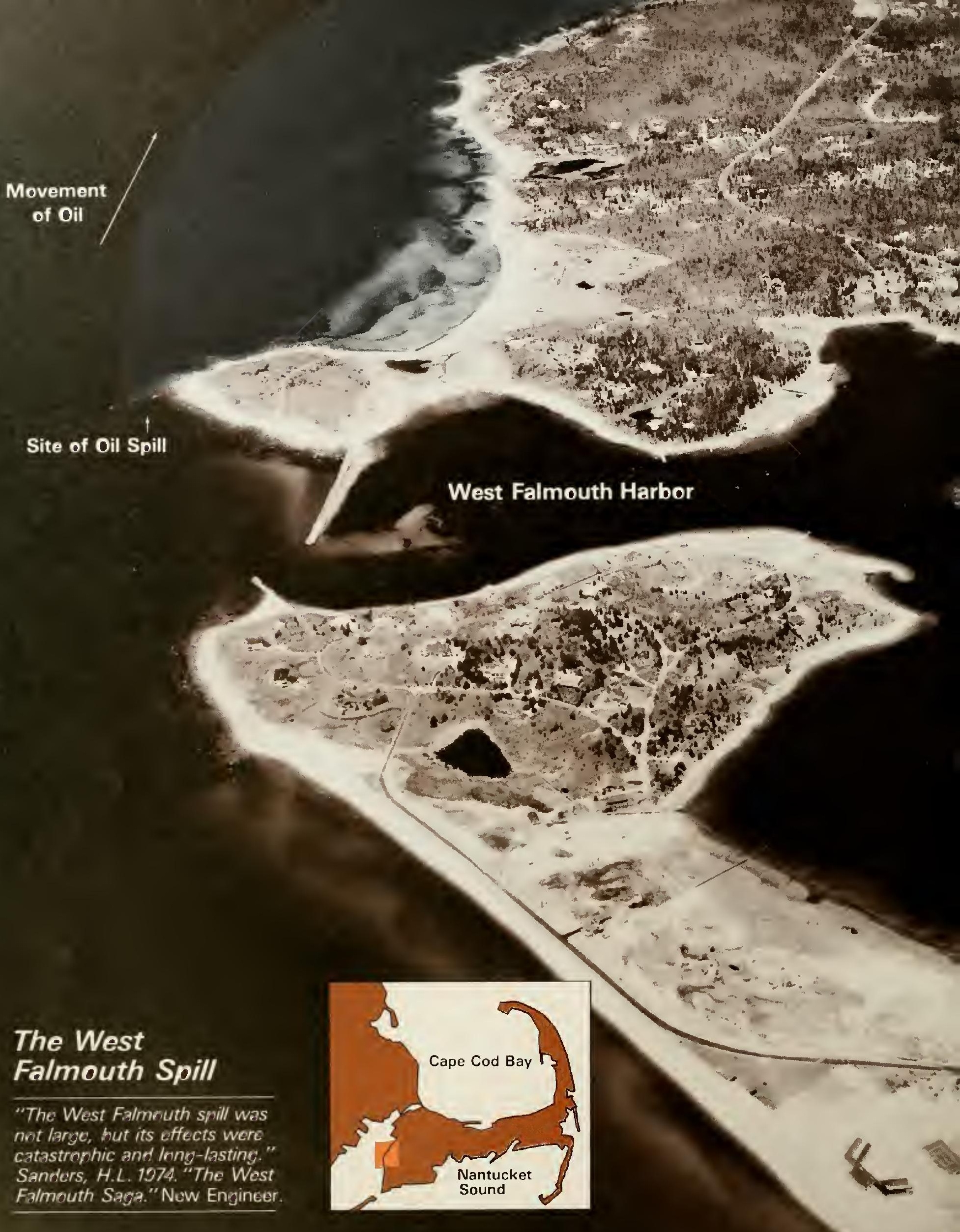




\section{Preface}

This is a report about oil and its effects in marine environments, a technically complex subject that is further shrouded by controversy between conflicting interests. This report focuses on an investigation of a modest oil spill which occurred at West Falmouth, Massachusetts in September, 1969. The West Falmouth study was conducted by Dr. Howard Sanders, the late Dr. Max Blumer, and their colleagues from the Woods Hole Oceanographic Institution. Substantially supported by EPA's Office of Research and Development, the work of Dr.

Sanders and his associates comprises what is probably the most rigorous and comprehensive investigation ever made of a single spill event. The West

Falmouth study provides a solid advance in the understanding of oil pollution in the ocean, and its effects on coastal areas.

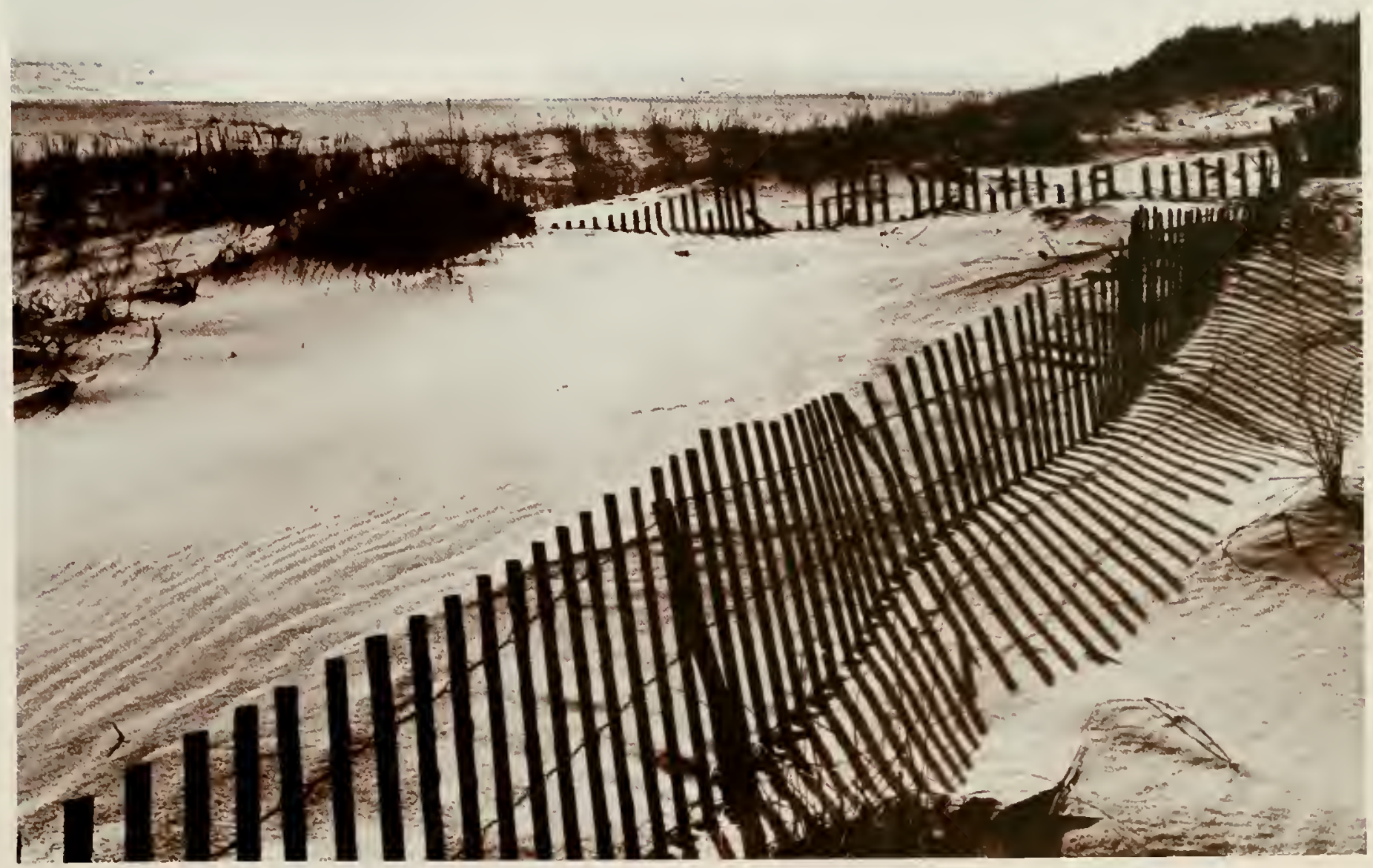




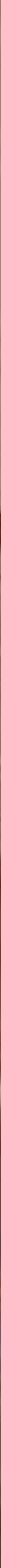




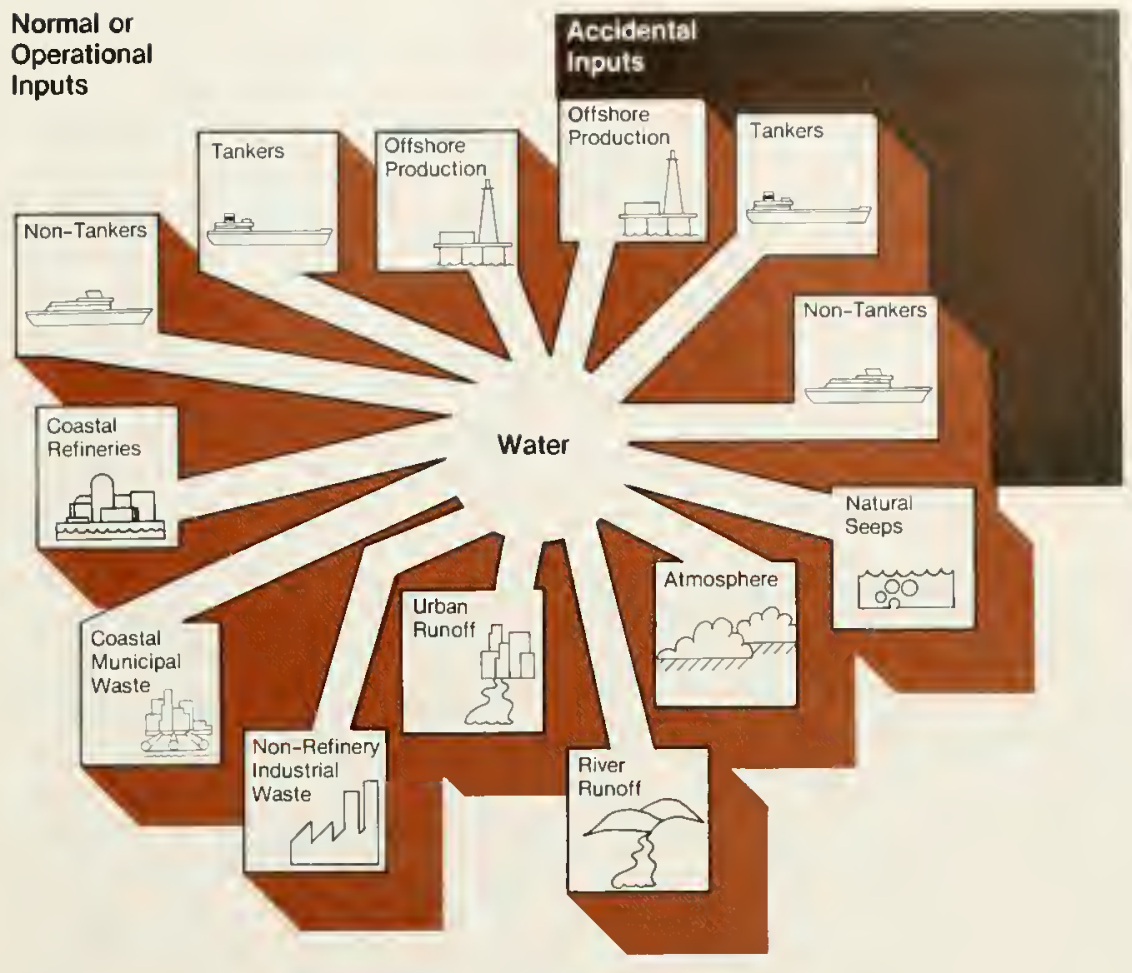

United States Sources of Petroleum Inputs to the Marine Environment

\begin{tabular}{|c|c|c|}
\hline Source of Oil & $\begin{array}{c}\text { Thousand Metric } \\
\text { Tons Per Year }\end{array}$ & $\begin{array}{l}\text { Percent of } \\
\text { Total }\end{array}$ \\
\hline \multicolumn{3}{|l|}{ Offshore Production } \\
\hline Normal Operations & 3 & 0.2 \\
\hline Accidents & 10 & 0.7 \\
\hline Subtotal & 13 & 0.9 \\
\hline \multicolumn{3}{|l|}{ Tankers } \\
\hline Normal Operations & 209 & 13.8 \\
\hline Accidents & 30 & 2.0 \\
\hline Subtotal & 239 & $\overline{15.8}$ \\
\hline \multicolumn{3}{|l|}{ Non-Tankers } \\
\hline Bilges Bunkering & 78 & 5.2 \\
\hline Accidents & 20 & 1.3 \\
\hline Subtotal & 98 & 6.5 \\
\hline Coastal Refineries & 30 & 2.0 \\
\hline Coastal Municipal Waste & 100 & 6.6 \\
\hline Non-Refinery Industrial Waste & 100 & 6.6 \\
\hline Urban Runoff & 100 & 6.6 \\
\hline River Runoff & 530 & 35.1 \\
\hline Atmosphere & 180 & 11.9 \\
\hline \multirow{2}{*}{ Natural Seeps } & 120 & 8.0 \\
\hline & $\frac{1,0}{1,510}$ & $\overline{100.0}$ \\
\hline
\end{tabular}

Source: National Academy of Sciences, 1974. Petroleum in the marine environment: Inputs, techniques for analysis, fates and effects. Ocean Affairs Board, NAS, Washington, D.C.

Although less than $3 \%$ of all oil entering the marine environment results from tanker and offshore production accidents, oil spills are unique because they create high concentrations of oil in the environment, and therefore pose a special kind of environmental threat.

\section{How Does Oil Get into the Oceans?}

It is estimated that more than 1.5 million metric tons ${ }^{*}$ of oil or petroleum products enter United States coastal waters each year. The bulk of these inputs result from human activities, mostly from urban and river runoff $(42 \%)$, and normal tanker operations which include cleaning tanks and ballasting $(14 \%)$. Although less than $3 \%$ of the oil enters coastal waters because of tanker and offshore produc tion accidents, such oil spills are important because they create higher concentrations of oil than do most other sources of oil pollution, and, therefore, pose a special kind of environmental threat.

An oil spill can happen whenever oil is transported, stored, handled or extracted from the earth. About 10,000 oil spills totalling 10 to 20 million gallons of oil can be expected in or near the territorial waters of the United States every year. However, the annual amounts of spillage are variable and dependent on the frequency of major oil spill disasters. A single accident involving a supertanker could spill more oil than the total annual spillage into all U.S. waters. The Amoco Cadiz, for example, lost over 60 million gallons of oil when it broke up off the coast of France in March of 1978. In U.S. waters, spilled oil is more frequently a problem in the Atlantic Ocean and the Gulf of Mexico than in the Pacific Ocean. A large portion of the spilled oil enters near-shore areas where winds and currents may transport the oil to pollution sensitive river outlets and bay areas (estuaries), tidal flats and marshes.

"One metric ton equals about 7 barrels. One barrel equals 42 U.S. gallons. 


\section{Amounts of Oil Spilled}

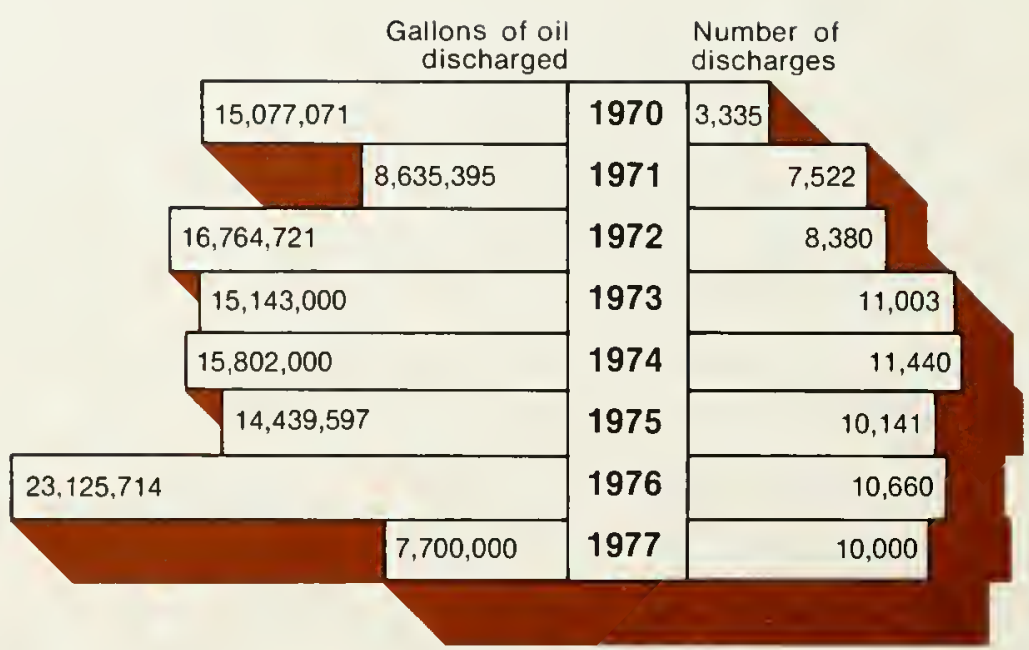

Source: USCG. Polluting Incidents in and around US Coastal Waters. 1975, 1976. CG-487.

\section{Location of Oil Spills (1976)}
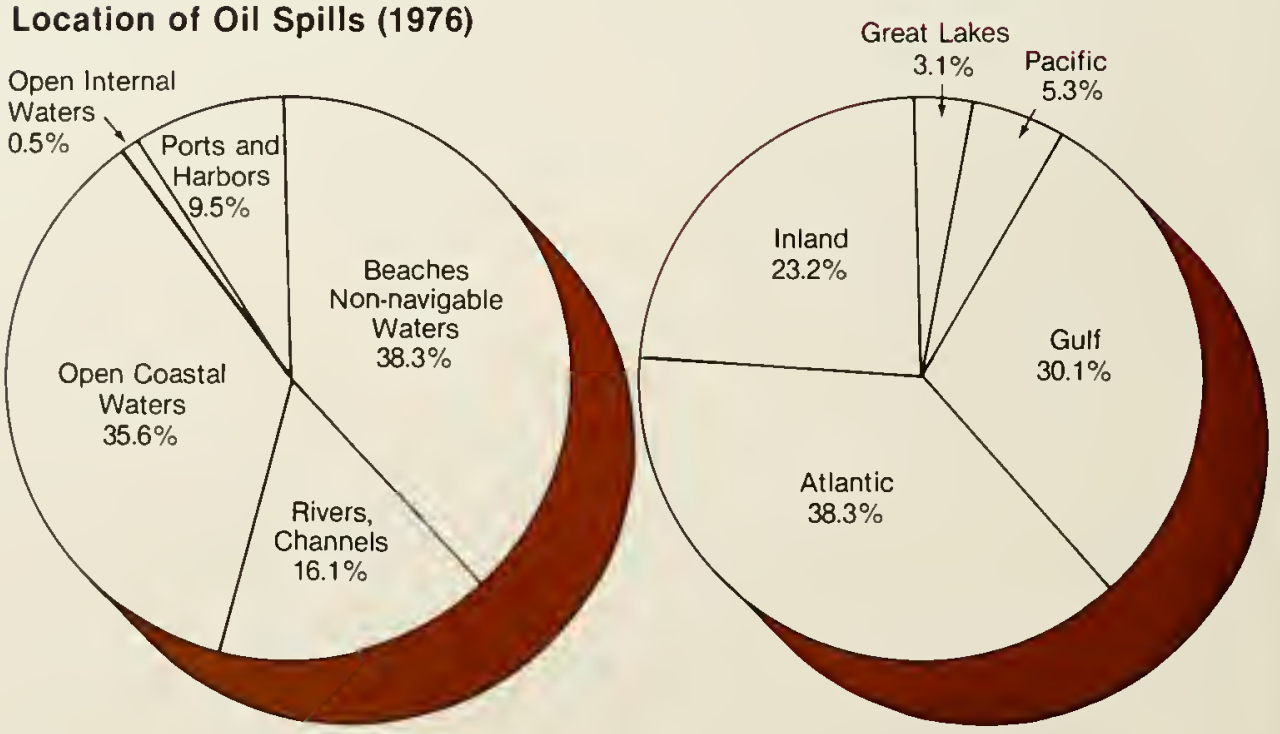

Source: USCG. Polluting Incidents in and around US Coastal Waters. 1975, 1976. CG-487. 


\section{What Are The Effects of Oil Spills?}

\begin{tabular}{lll}
\hline Area of Comparison & Argo Merchant & Barge (STC-101) \\
Location of Spill & Atlantic Ocean & Chesapeake Bay \\
Cargo & No. 6 Oil & No. 6 Oil \\
Size of Spill & $7,500,000$ gals. & 250,000 gals. \\
Shoreline Contaminated & None & 27 miles \\
Waterfowl Killed & 540 & 31,000 \\
$\begin{array}{l}\text { Total Cost of Lost } \\
\quad \text { Waterfowl (based on } \\
\quad \text { monetary value assigned }\end{array}$ & $\$ 5,535$ & $\$ 635,325$ \\
$\quad$ to lost species) & & \\
\hline
\end{tabular}

Source: Total Costs Resulting from Two Major Oil Spills. 1977. CED-77-71.

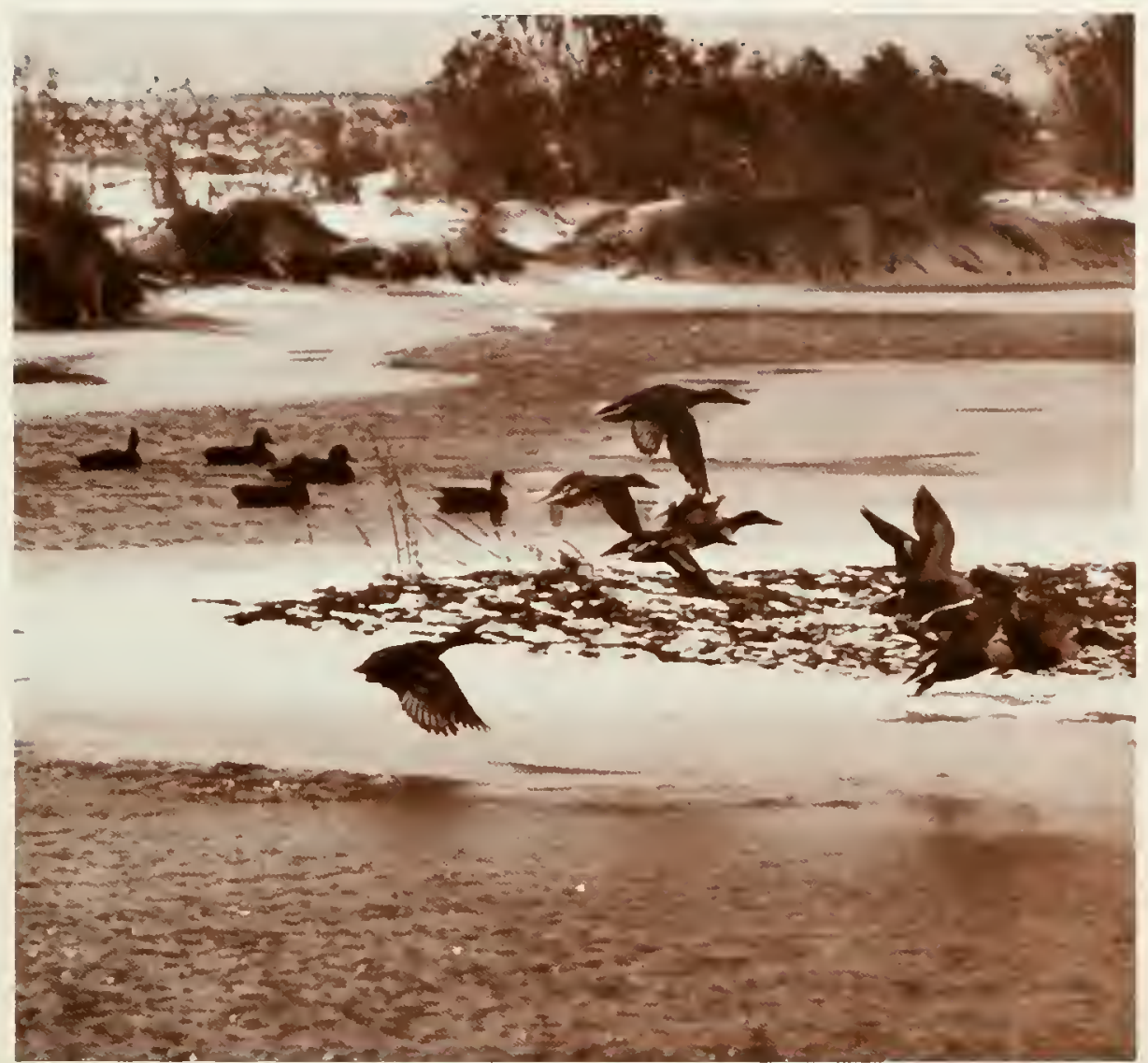

Each spill is a unique event, with a number of factors interacting to determine the effects of a specific spill. For example, two spills that occurred in 1976 have been compared by the Comptroller General of the United States. The Argo Merchant went aground on shoals 30 miles southeast of Nantucket, while the Barge (STC-101) was grounded 4 miles offshore near the mouth of the Potomac River.

Even though the Argo Merchant spill was more extensive, spilling thirty times more oil, the impact was greater on the Chesapeake Bay as waterfowl were flocking in great numbers during seasonal migrations. Because the bay enclosed and retained the oil, the effect was prolonged and magnified. These effects illustrate the difficulty of predicting, except in a general way, what the exact environmental impact of a given spill will be. The type and amount of oil spilled, the weather and the direction of ocean currents, the coastal areas and organisms impacted, the season, and the effect of cleanup attempts each play a role in determining the impact of an oil spill. Previous exposure of marine plants and animals, and their environment to spilled oil may alter the sensitivity of such an ecosystem to additional spills. The significant environmental effects of spilled oil, which result from oil toxicity and physical coating, range from direct kills of fish and wildlife to more insidious sublethal effects such as reducing the ability of organisms to reproduce or to follow normal behavior patterns.

In the case of the 1969 West Falmouth spill, very sensitive habitats and organisms were exposed to oil. The spill was of moderate size, about 175,000 gallons, but the highly toxic No. 2 fuel oil contaminated the local estuary and marshes and caused significant losses to commercial fisheries and serious long-term damage to the marine ecosystem in the West Falmouth area. 


\section{The West Falmouth Spill}

"It was John L. R. French ... who first called the Coast Guard. He was awakened about 12:30 a.m. by the stench of oil. Like others, he thought first it was from his own oil burner." from The Falmouth Enterprise, September 16, 1969.

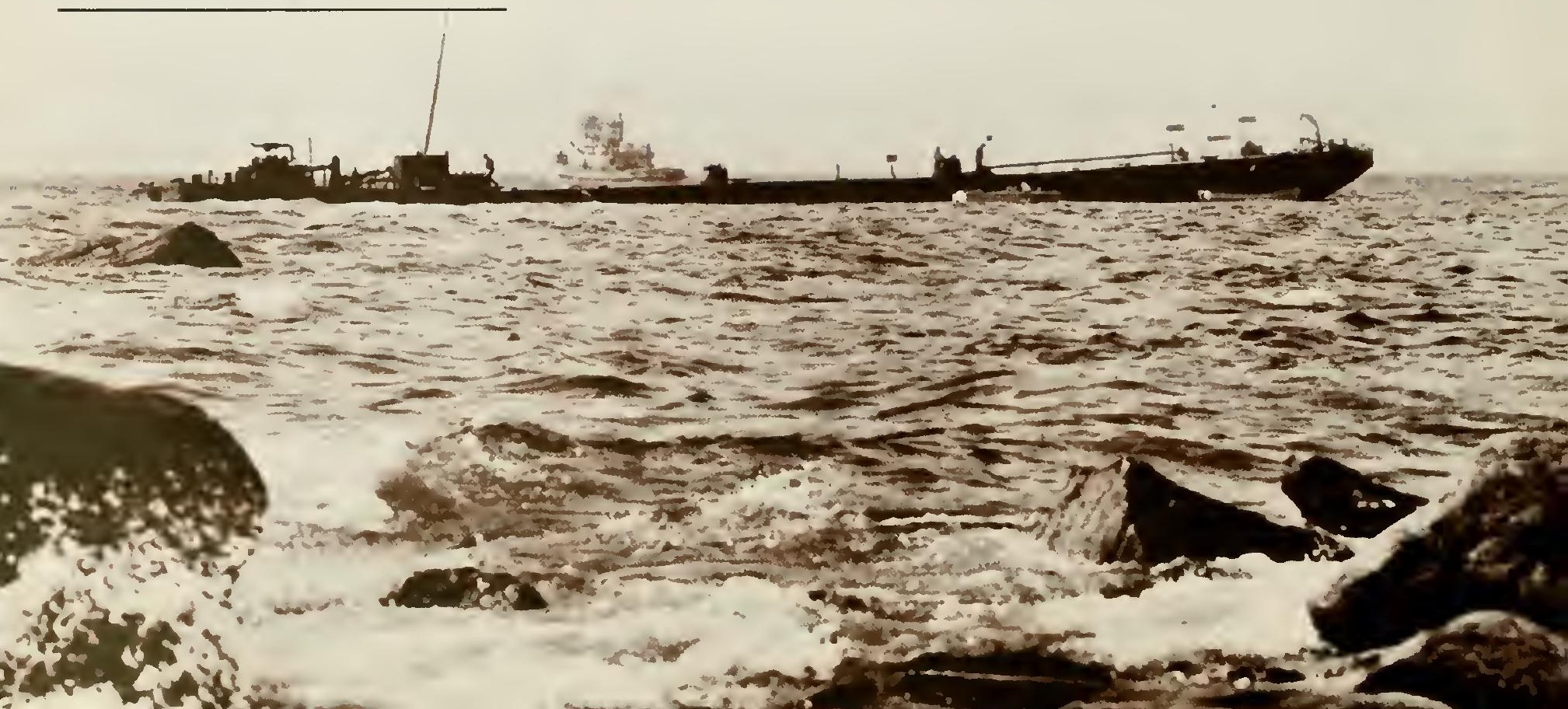




\section{What Happened at West Falmouth?}

On the evening of September 15, 1969 , a tug pulling a barge out of Tiverton, Rhode Island, had started up Buzzard's Bay bound for a power plant on the Cape Cod Canal. During the night, the radar failed and the towline broke. In the fog, the barge Florida went aground on submerged boulders near the mouth of West Falmouth Harbor. The Florida was damaged and leaking her 2500 ton cargo of No. 2 fuel oil into the waters of West Falmouth. Before the barge could be lightened and freed from the rocks, about 550 tons or 175,000 gallons of the light refined oil were lost.

In the water, the oil formed a coffee colored emulsion of water and oil that was visible for several miles. The slick was driven north-northeast by strong winds toward Wild Harbor. Efforts at containing or otherwise mitigating the impact of the spilled oil included the use of booms or floating barriers, and two types of chemical dispersants to break up the oil. These efforts had little or no effect on the movement and impact of the spilled oil. Miles of beach were littered with windrows of dying, dead, and decaying marine organisms. With each tide, the windrows were replenished with more casualties of scallops, lobsters, finfish, marine worms, and various other marine organisms. The oil had obviously impacted the marshes and tidal areas of Wild Harbor.

At the time, the event attracted little national attention. The spill was not large and some oil spill professionals, such as the president of the cleanup company, predicted a full recovery in four to six weeks. However, Town of Falmouth Shellfish Constable George
Souza knew that the problem was more serious. Mr. Souza made a personal survey of the local beaches, marshes and waters. He estimated the immediate loss to the local shellfishing industry to be $\$ 250,000$. Mr. Souza's estimate included only the immediate mortality of scallops and soft-shell clams. He did not consider the loss to other commercial fisheries products such as lobsters, finfish and hard-shell clams (quahogs), nor the secondary impacts to fish processing, transporting, wholesaling and retailing industries that would be experienced in years to come.

Principal Falmouth shellfishing areas were closed for several years following the spill. Shellfishing in the Wild Harbor Basin and Wild Harbor River is still restricted today, ten years after the spill. Because of the severe local economic impact of the spill, the Town of Falmouth and the State of Massachusetts filed suit against the owner of the Florida. In an out-of-court settlement, the Town of Falmouth received $\$ 100,000$ and the State of Massachusetts received $\$ 200,000$ in payment of damages.

\section{What About Scientific Studies?}

It is relatively easy to estimate the dollar impact of the West Falmouth spill on local fisheries. It is a much more difficult matter to document, interpret and understand the immediate and long-term impacts of the spill to the ecosystems of the West Falmouth area. The spill occurred only a few miles from the Woods Hole Oceanographic Institution and the Woods Hole Marine Biological Laboratory which are among the most respected oceanographic research centers in the world. The chance proximity of the spill site to Woods Hole provided an excellent opportunity for a scientifically rigorous documentation and analysis of the effects of a single oil spill event. This is precisely what the Woods Hole researchers, led by Dr. Howard Sanders, Mr. George Hampson and Dr. Max Blumer, set out to do. Through the years, twelve scientific investigators have examined different aspects of the West Falmouth spill. Research efforts have included chemical analyses, sediment analyses, long-term studies of benthic (bottom-dwelling) organisms, studies of the marsh ecosystems and detailed investigations of the biology of fiddler crabs and killifish of Wild Harbor marsh. Taken together, these studies provide a detailed account of the effects of the West Falmouth spill, making it the most studied and best understood oil spill to date. 


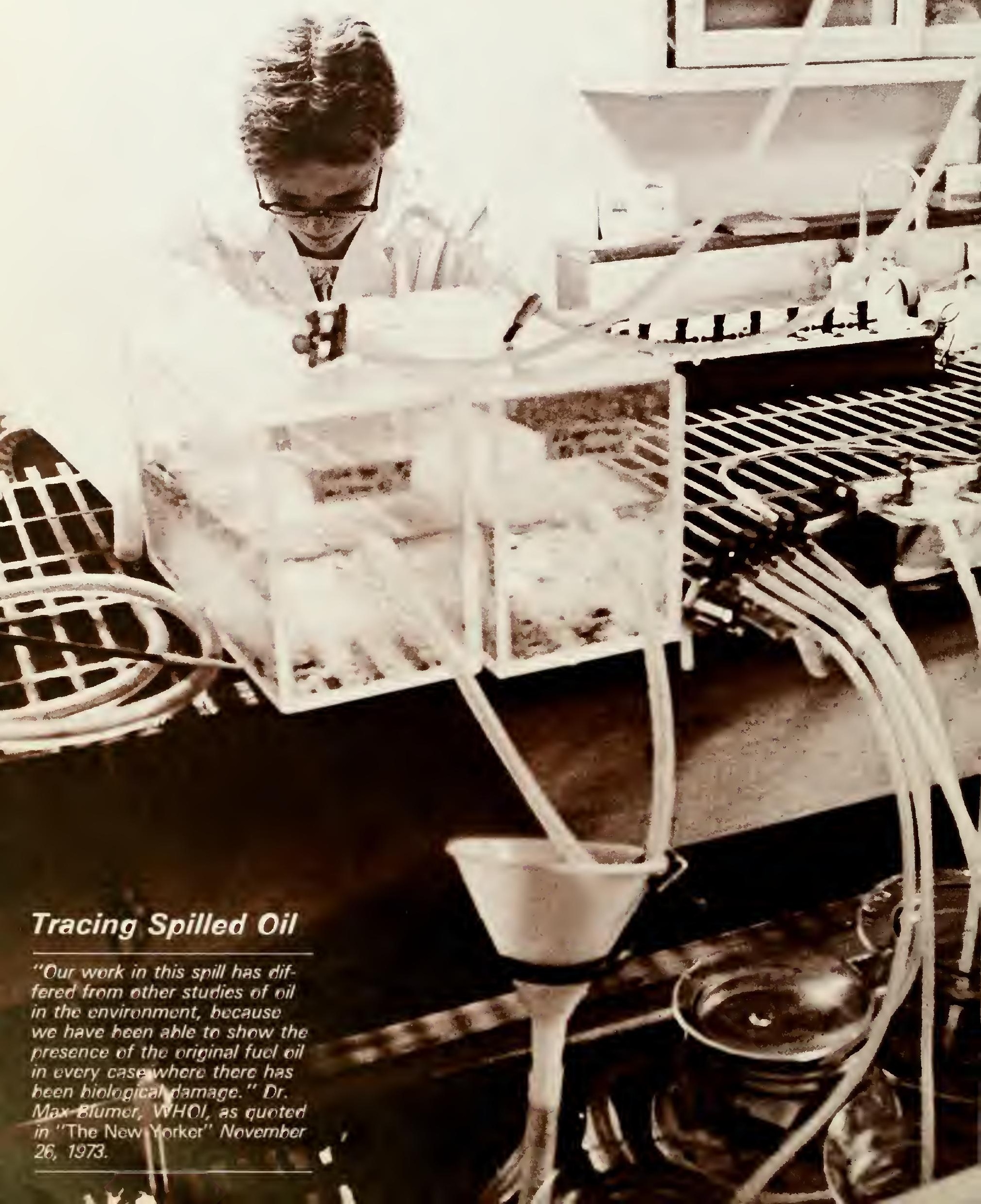




\section{Why Trace Spilled Oil?}

Reports from the West Falmouth area suggested that everything was back to normal shortly after the cleanup operations were terminated. Bathers were enjoying the water, and the beaches were as beautiful as ever. These reports were misleading. When spilled oil can no longer be seen, it does not mean that the oil, at toxic levels, is not present. Oil can be lethal or have significant sublethal effects in very small concentrations, concentrations as low as several parts per billion.

Sensitive analytical techniques can detect these very small, but important, concentrations of oil. The techniques of analytical chemistry can also differentiate between hydrocarbons from petroleum and the naturally occurring or biogenic hydrocarbons that are present in all living things. One analytical technique, gas chromatography, can even distinguish between different types of oil.

Analytical chemistry provides the tools used to trace oil as it disperses into the environment, to monitor changes in the oil that occur as a result of weathering, and to relate this information to biological surveys and studies of organisms.

A

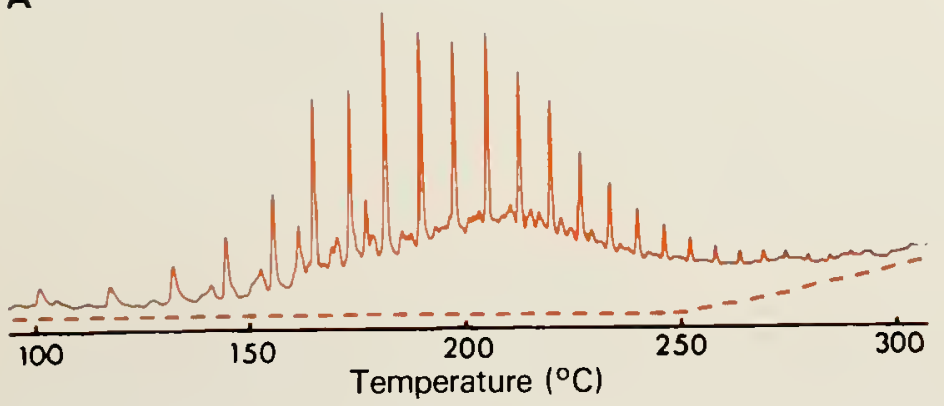

B

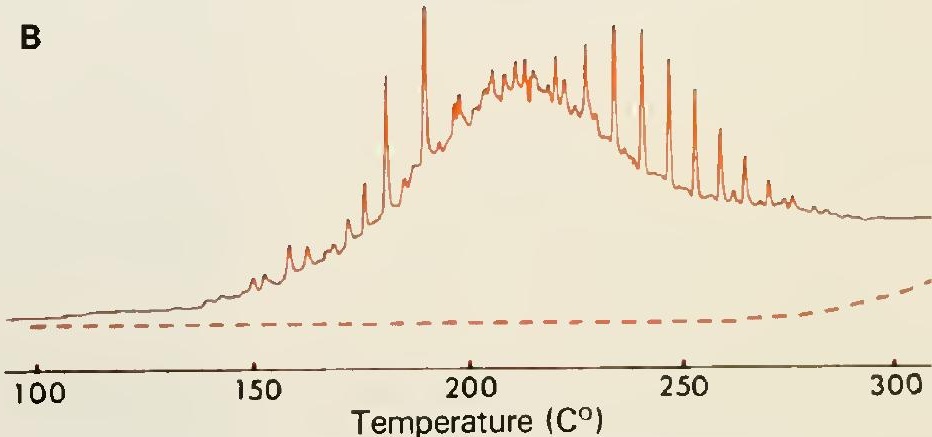

Gas chromatogram "fingerprint" of fresh No. 5 fuel oil (A) and the same oil after weathering for $4 \frac{1}{2}$ months (B). 


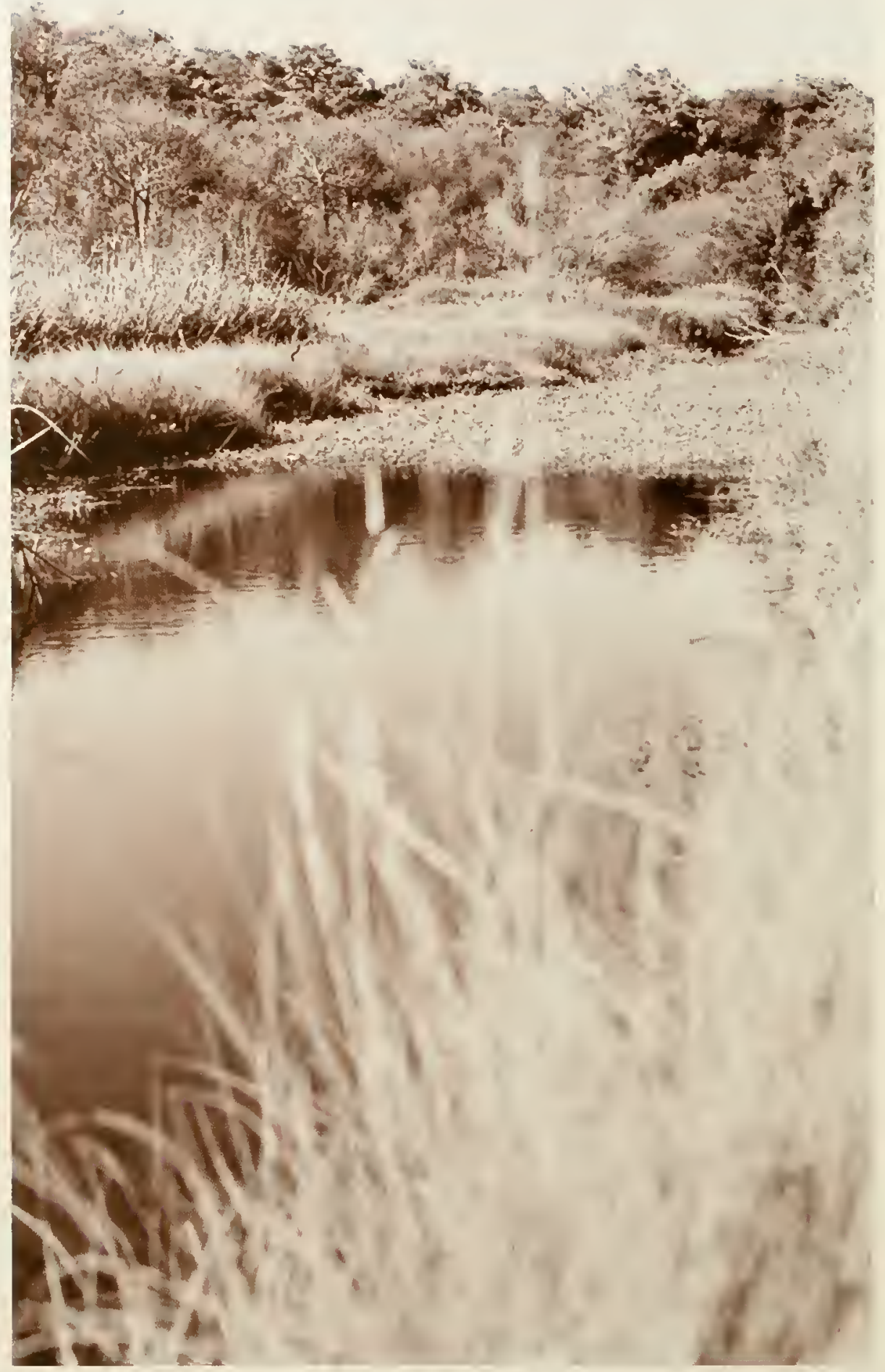



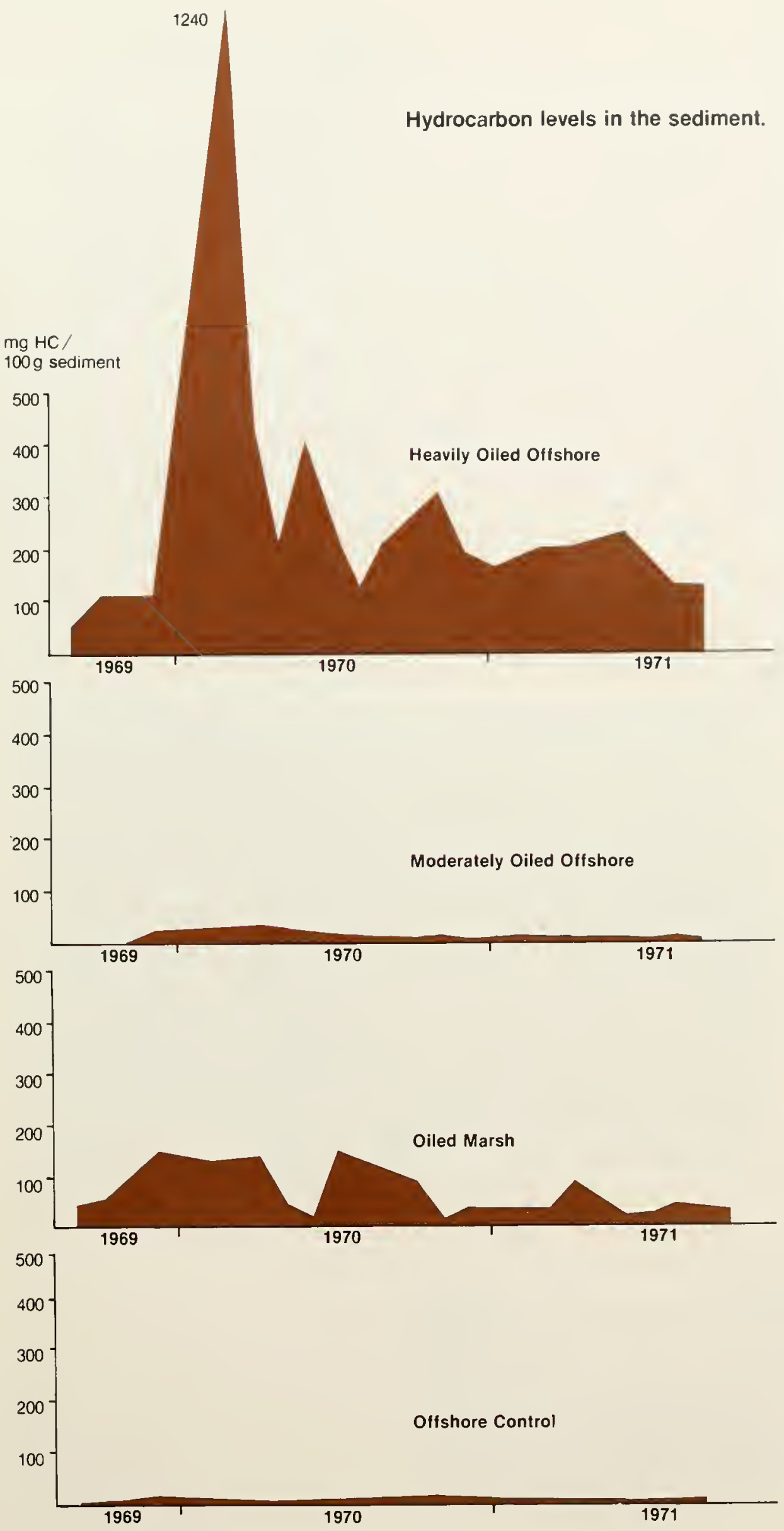

\section{Where Did the Oil Go?}

Once released into the water, the fate of the No. 2 fuel oil from the Florida was dictated by the physical, chemical and biological characteristics of the ecosystem. Initially the oil was blown to the north-northeast and a large amount was incorporated into the sediments of the heavily oiled subtidal area. Other subtidal areas were moderately or lightly oiled. Fuel oil was also found in the marshes of the Wild Harbor River. In the weeks following the spill, the No. 2 fuel oil continued to disperse. Some sampling sites that were chemically and biologically "normal" immediately after the spill were found to be contaminated one to three months later. During the chemical monitoring, all polluting hydrocarbons were very similar, by "fingerprint," to the oil carried by the Florida. By the spring of 1970 , the subtidal polluted area was ten times larger than immediately after the spill, covering 5,000 acres. At that time 500 acres of marsh and river were also polluted.
Source: Sanders, H.L., et al. IN PRESS. Anatomy of an Oil Spill: The West Falmouth Study. (Submitted to EPA) 
"Fingerprints" of Sediment Oil
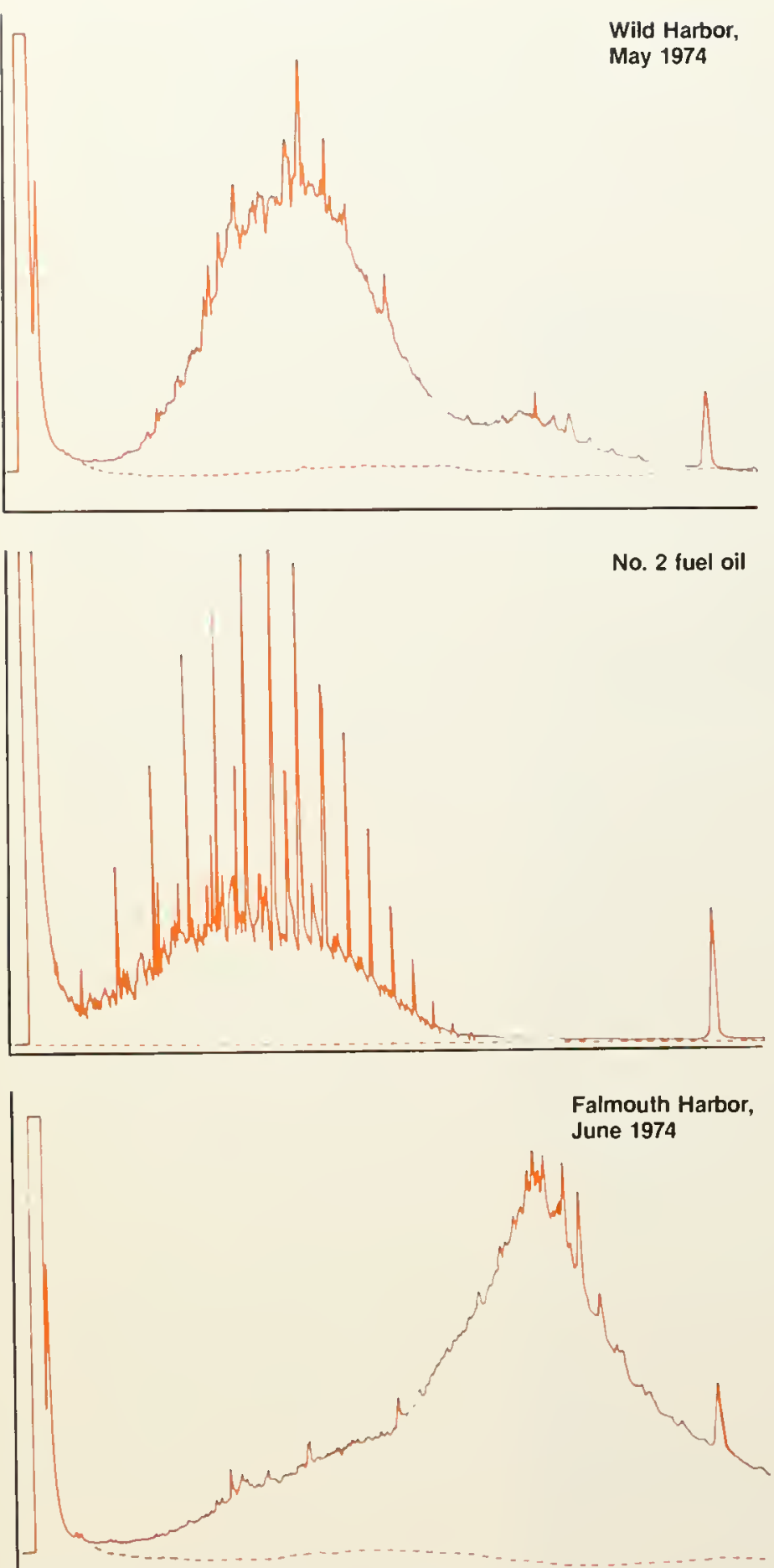

Source: (A) Sanders, H.L., et al., IN PRESS. Anatomy of an Oil Spill: The West Falmouth Study (submitted to EPA). (B, C, D) Michael, A.D., C.R. Van Raalte and L.S. Brown. 1975. Long-Term Effects of an Oil Spill at West Falmouth, Massachusetts. Proceedings of Conference on Prevention and Control of Oil Polution. API.

Gas chromatography shows that the hydrocarbons in the sediment at Wild Harbor were more similar to No. 2 fuel oil than to hydrocarbons commonly found in nearby Falmouth Harbor.

\section{How Persistent Was the Oil?}

At West Falmouth, the spilled oil has persisted for over ten years. Even today, relatively fresh No. 2 fuel oil can be found in the marshes of Wild Harbor. In general, hydrocarbon levels in the sediments of oiled stations have tended to decrease slowly over time. The major processes responsible for this decrease are dissolution, or dissolving into the water, and biodegradation, which is breaking down of matter by living organisms.

Once in the environment, oil may be redistributed, dispersed or concentrated as time passes. For example, in March 1970 there was a dramatic increase in the amount of sediment oil at the heavily oiled Wild Harbor sampling station. The "fingerprint" technique showed that the hydrocarbons in Wild Harbor sediments, as late as 1974 , were more similar to those of No. 2 fuel oil than to the hydrocarbons found in the sediments of Falmouth, a nearby polluted harbor. The source of this oil is thought to be the sponge-like marshes of the Wild Harbor River, where the original No. 2 fuel oil is still leaching out.

Organisms within the ecosystem absorb, ingest, accumulate, and distribute petroleum hydrocarbons. Woods Hole researchers K.A. Burns and J.M. Teal found traces of polluting hydrocarbons in the plants and animals of Wild Harbor marshes twelve to eighteen months after the West Falmouth spill. The lingering residue of No. 2 fuel oil was found in birds, algae, marsh grass, mussels, and fish from the Wild Harbor River area, but samples from the nearby Sippewissett Marsh control station were uncontaminated. 


\section{Where is the West Falmouth Oil Today?}

Oil is a complex mixture of slowly degrading hydrocarbons. The degradation of oil is especially slow in environments such as mud flats, marshes and muddy bottom sediments. The West Falmouth studies show that in areas where heavy oiling occurred, chronic oil pollution has lasted for years.

Although techniques of analytical chemistry have documented the fate of the oil spilled by the Florida, the key to further understanding of the impact of the spill is in looking at the biological effects.

\section{Fate of Oil}

- Heavy oiling occurred at subtidal and intertidal areas.

- Plants and animals were contaminated with No. 2 fuel oil.

Collected about six months after the spill, these mussels demonstrate some sublethal effects of the West Falmouth oil spill. The Wild Harbor mussels on the left are emaciated compared to the healthy mussels from nearby Sippewissett Marsh which are plump with eggs and sperm.

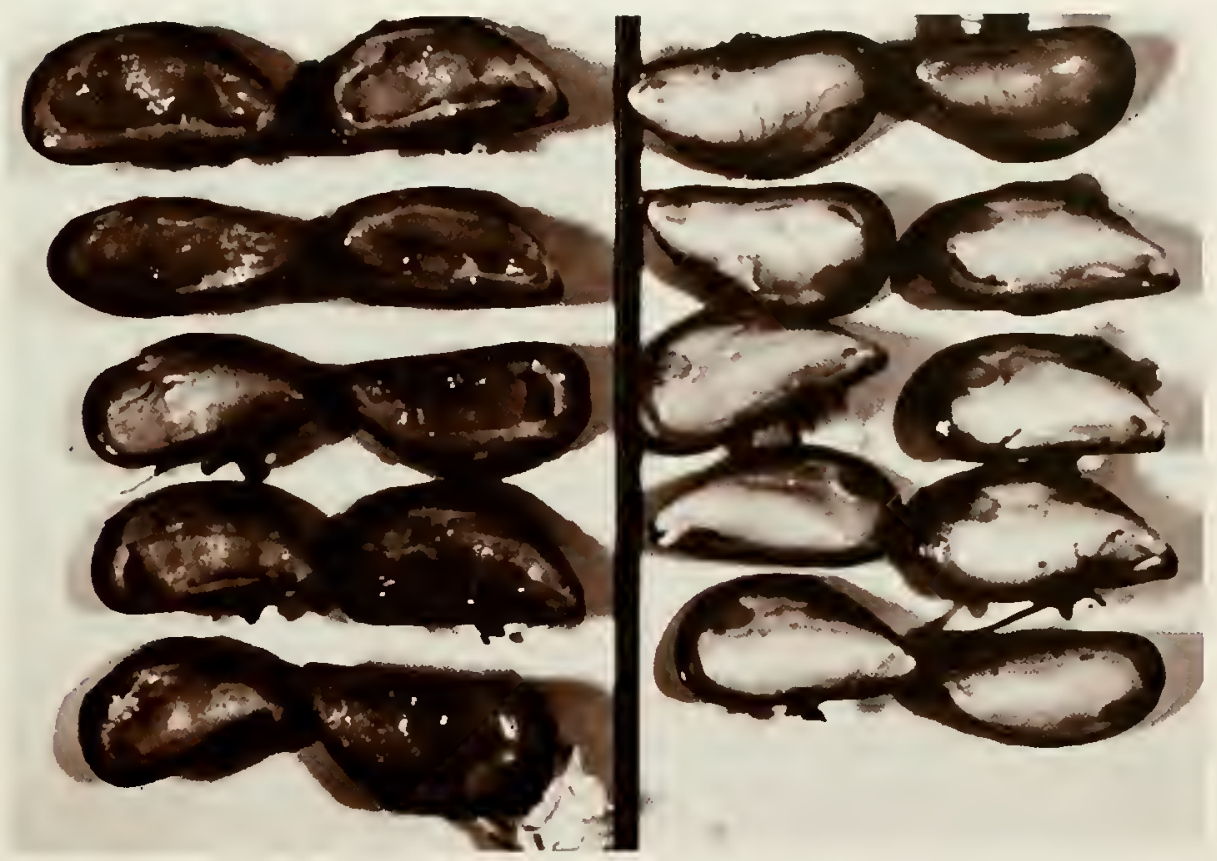

- The No. 2 fuel oil persisted for years after the spill, clearly refuting the frequently stated assumption that all light oils are quickly dissipated in the environment.

- Heavy oiled areas served as sources of low level chronic oil repollution: a single spill can cause a chronic oil pollution problem.

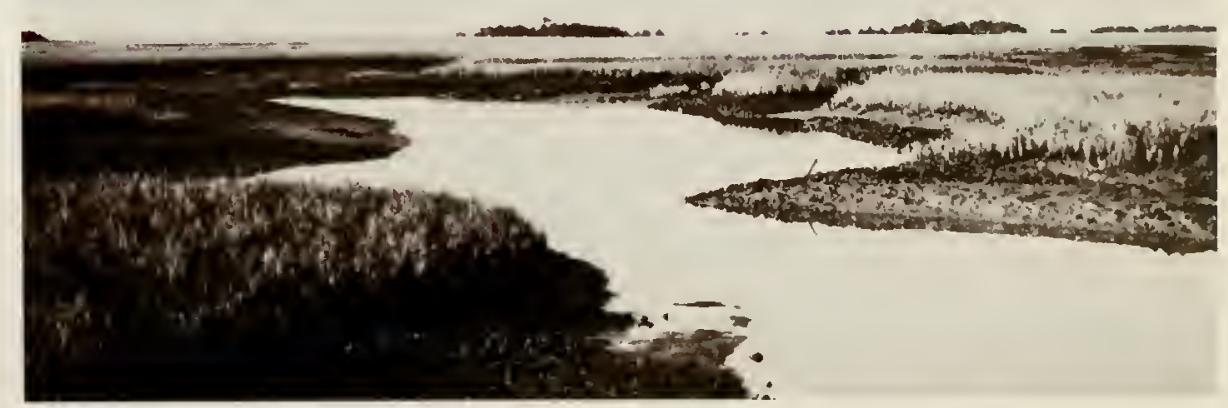




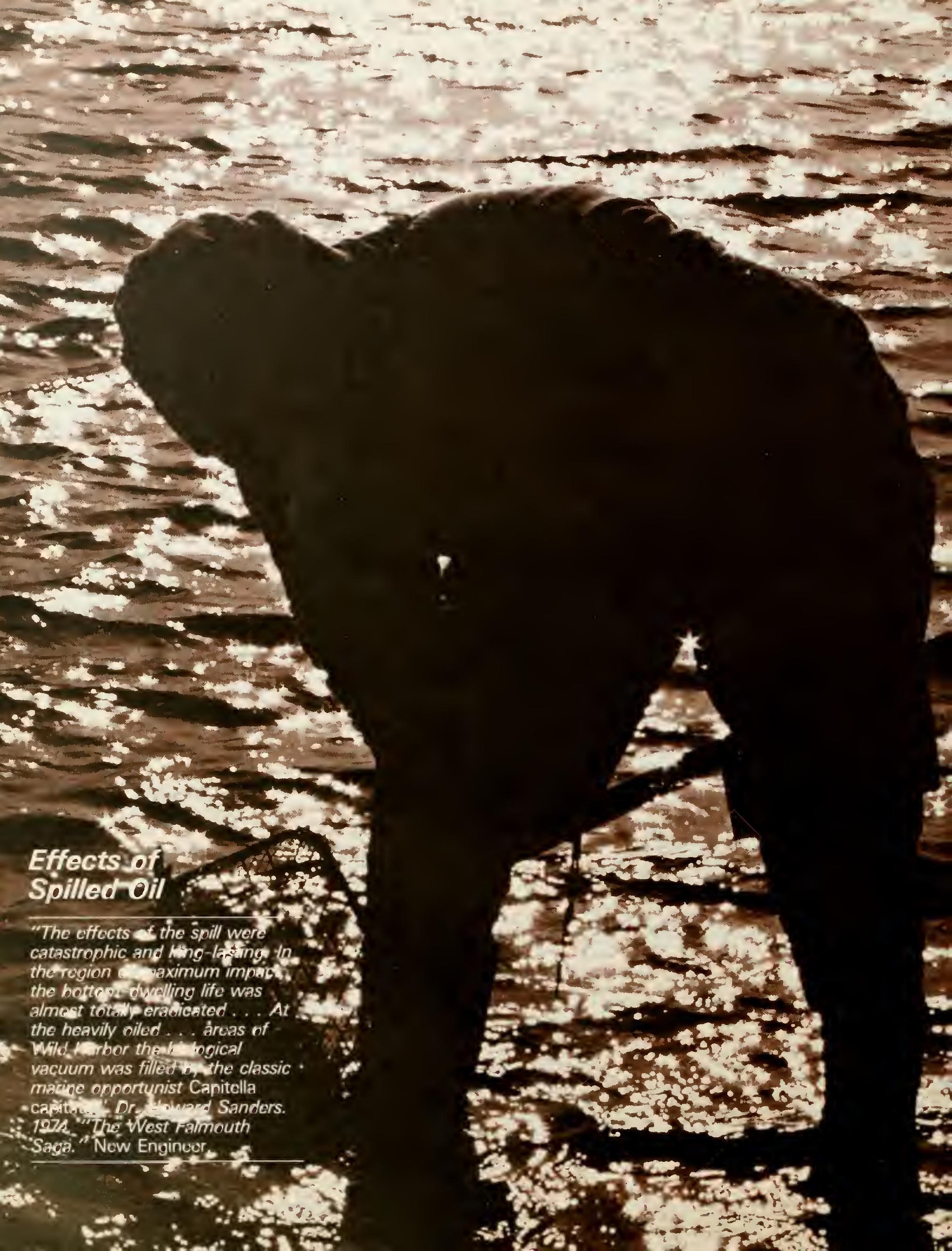




\section{What Kind of Research Was Done?}

The researchers at the Woods Hole Oceanographic Institution were presented with the problem of developing an experimental design that would best document the effects of the West Falmouth spill on benthic (bottomdwelling) communities of marine animals, whether the effects were gross, subtle or non-existent. This involved deciding where, when and how bottom samples would be taken, processed and analyzed. The major factors considered in making these decisions were the distribution of the oil, the expected rates of change in the benthic communities, and the stateof-the-art of benthic sampling and sample processing.

\section{Sampling Methods}

Where - Chemical analysis of bottom samples was used to determine where biological samples would be taken. The aim was to sample heavily oiled, moderately oiled and lightly oiled or control stations. This allowed comparison of community response to different levels of pollution. Two types of communities were sampled, the in tertidal marsh and the subtidal offshore. Sediment types found at sampling stations were compared to ensure that subtidal stations represented the same basic bottom community type.

When - Deciding when and how frequently to sample is difficult. Seasonal and spatial differences in normal benthic communities are considerable, and communities under stress may vary even more dramatically. On the other hand, to acquire and process benthic samples is time consuming and costly. Sampling was initiated immediately after the spill, and it was decided to sample frequently, every month when possible. As time passed the frequency of sampling decreased somewhat.

How - Bottom samples were collected with a hand-held coring device at the intertidal marsh stations, and with a remote operated grab at the subtidal stations. A small portion of each sample was frozen and stored for chemical analysis. The biological samples were washed using a fine sieve, and the material retained on the sieve, including the animals, was placed in a preservative solution. In the laboratory, the animals were sorted from the debris using a microscope; identified and counted. The data analysis ranged from simple tallies of species and individuals to various statistical characterizations of the benthic communities.

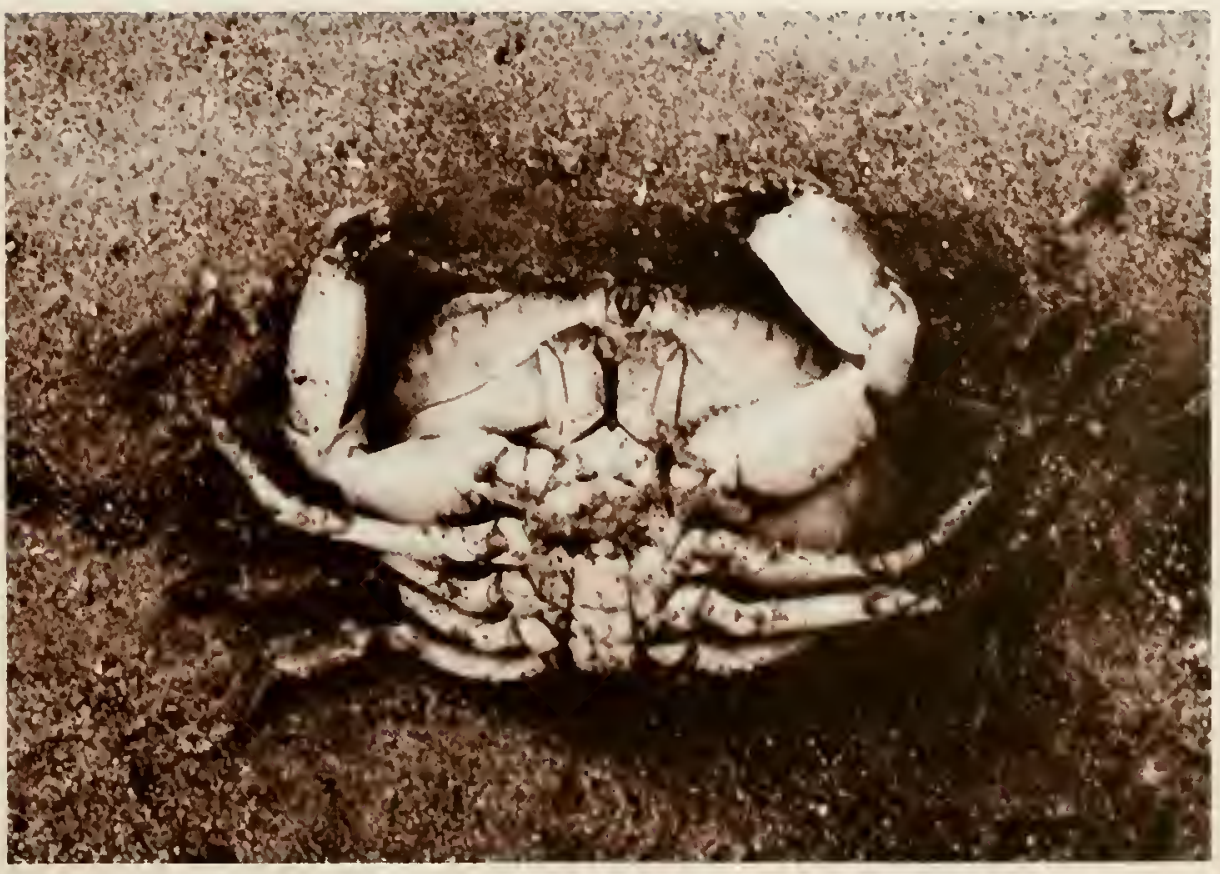




\section{Why Study Benthic Communities?}

Most people don't have any direct contact with the abundant but small organisms that live in marine bottom sediments. Therefore, it may be difficult to appreciate the importance of benthic communities even though we are all familiar with some of the larger bottom-dwellers such as the crabs, lobsters, clams and shrimp that are commonly enjoyed seafood items. But close study shows that ecosystems, including those of the benthos, are complex. The existence of one component of this system, such as crabs, depends on the normal functioning of all ecosystem components from bacteria to top predators such as striped bass. Many delicately balanced variables create an intricate marine ecosystem in which each component has some influence on all the others.

And so benthic communities are closely studied because the stationary lifestyle of such organisms makes them good pollution indicators, and because benthic communities play an essential role in the functioning of the ocean ecosystem.

\section{Importance of Benthic Communities}

Food Web Functions - One phenomenon observed in ecosystems is the transfer of energy up the food web, from plants to plant eaters or herbivores, to predators. Benthic organisms have a critical role in the transfer of energy to fish species, especially juveniles, the young of the species, and bottom feeding fish. Some benthic organisms concentrate food and energy from the water column by filtering out minute plants and animals. Others ingest sediment, in order to digest out the myriad microorganisms that in turn survive by breaking down dead plant and animal matter. Thus the benthic community might be thought of as an array of energy packets distributed at different sediment depths and available in different sizes and types. These energy packets may be grazed upon by a variety of finfish and shellfish, many of which are commercially important species.
Provision of Habitat - A structured or sheltering habitat is needed by many marine animals. The plants found in marshes and grass beds, which are associated with near-shore benthic communities, provide the habitat that helps make these areas so highly productive. These plants supply protected spawning areas, hiding places for small fish, and points of attachment for a host of sessile or attached marine species that are low in the food web, such as barnacles. This promotes the use of marshes and grass beds as nursery areas for many marine animals, including off-shore and commercially important species.

Lack of Motility - Many benthic organisms cannot relocate. Once the free-swimming larvae settle out of the water column and change into adults, they stay in the same location for the remainder of their existence. Although some benthic organisms are capable of relocating, for most it is a slow, poorly directed process, not at all comparable to the motility enjoyed by finfish.

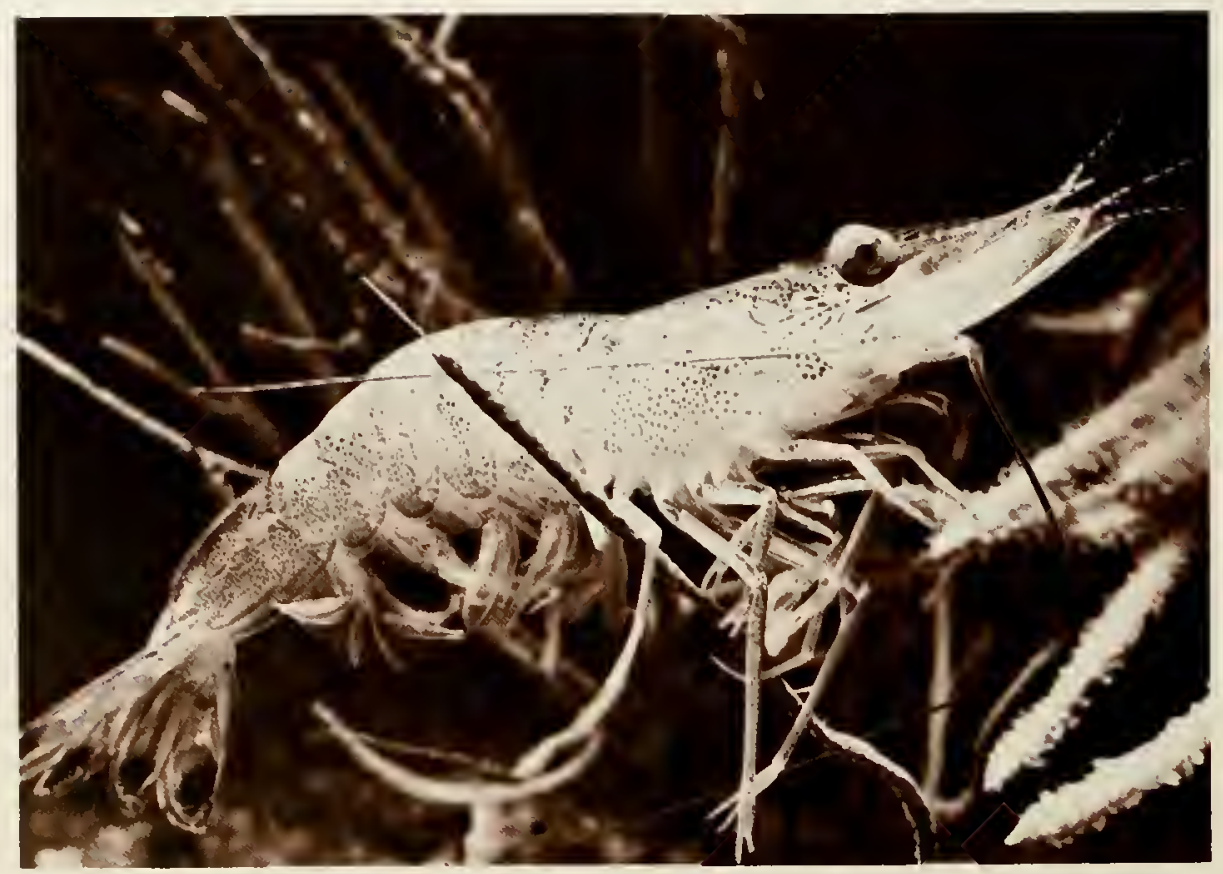




\section{What Were the Immediate Effects of the Oil Spill?}

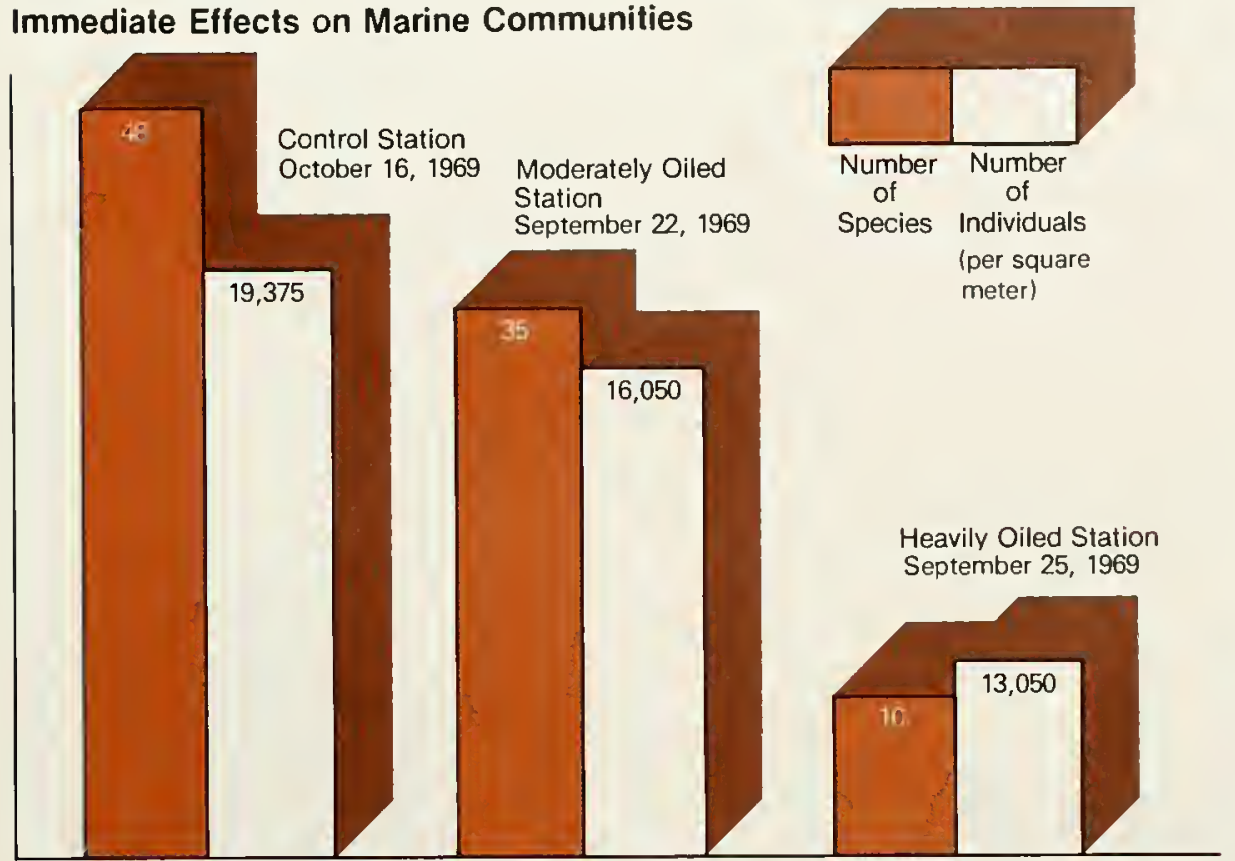

Source: Sanders, H.L., et al. IN PRESS.

Anatomy of an Oil Spill: The West Falmouth

Study. (Submitted to EPA)
Initial observations and samples taken soon after the West Falmouth spill revealed mass mortality in the benthic communities. Bottom dwelling species such as the lobster, tomcod and scup washed up on the beaches, indicating that subtidal benthic communities had been impacted. To confirm this, the researchers trawled the bottom off New Silver Beach in about ten feet of water. The results of the trawl were dramatic. The catch consisted of several species of fish, worms, crustaceans and other marine invertebrates. About $95 \%$ of the animals were dead, the rest, dying. The results of this and similar observations prompted the initiation of a comprehensive study of the effects of the West Falmouth spill on the benthos.

The initial samples clearly demonstrated the severity of the spill impact. Compared to control areas, oiled areas were reduced in both numbers of species and densities of benthic animals. This was true for both offshore and marsh sampling sites. Whenever oil was found in the sediment, there was mortality. The greater the concentration of oil, the greater was the observed mortality. Shortly after the initial impact, an opportunistic or "weed" species of worm called Capitella capitata underwent an impressive population explosion. Like weeds on a cleared lot, the prolific and resistant worm species took advantage of the biological void created by the spill at heavily oiled stations. In February $1970,99 \%$ of the individuals at marsh Station IV were Capitella as compared with the finding of no Capitella at a similar non-oiled site nearby. 
For years after the initial mortality, the benthic communities were in various stages of recovery. While recovering, the communities were characterized by reduced numbers of species, and several abnormal variations in community structure. From chemical monitoring, it was apparent that, in many cases, the capacity of the community to recover was compromised by the repollution, multiple exposures, and persistence of the No. 2 fuel oil in the environment.
The communities that were recovering after oiling showed many basic differences when compared to normal benthic communities which were represented by control stations.

In light of this evidence, there is no question that the normal functioning of benthic communities was profoundly affected for years after the West Falmouth spill.
Stages of RecoveryNumber of Bottom Dwelling Species
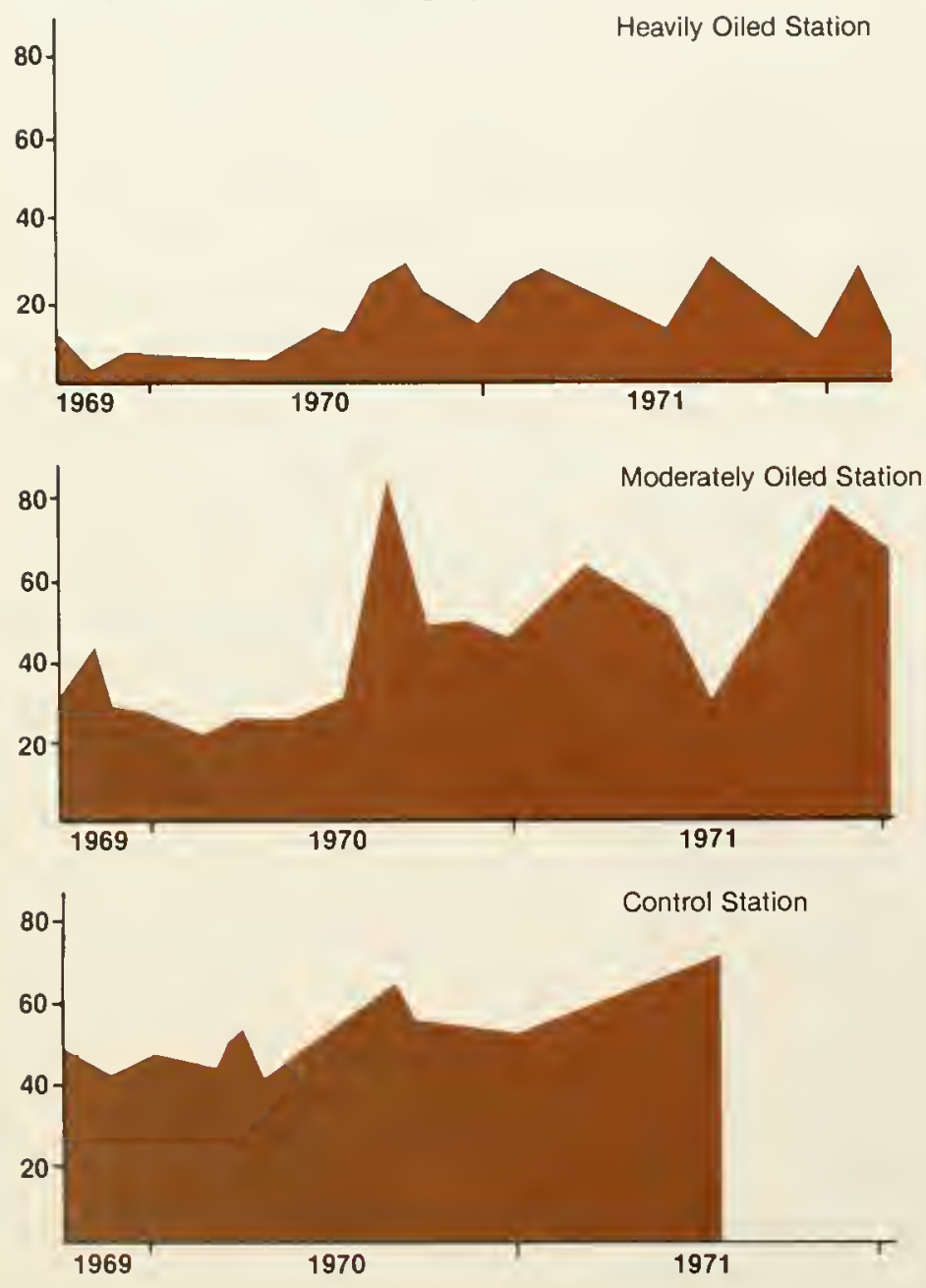

Recovery of Affected Communities

- Smaller numbers of species.

- Community dominance by opportunistic species.

- Increased fluctuation, over time. in the numbers of benthic organisms making up the community.

- Greater variation, over time, in the species composition of the recovering community.
Source: Sanders, H.L., et al., IN PRESS. Anatomy of an Oil Spill: The West Falmouth Study. Draft Submitted to EPA. pp. $85,86,87$. 
Domination of Weed Species Percentage of Capitella in Community
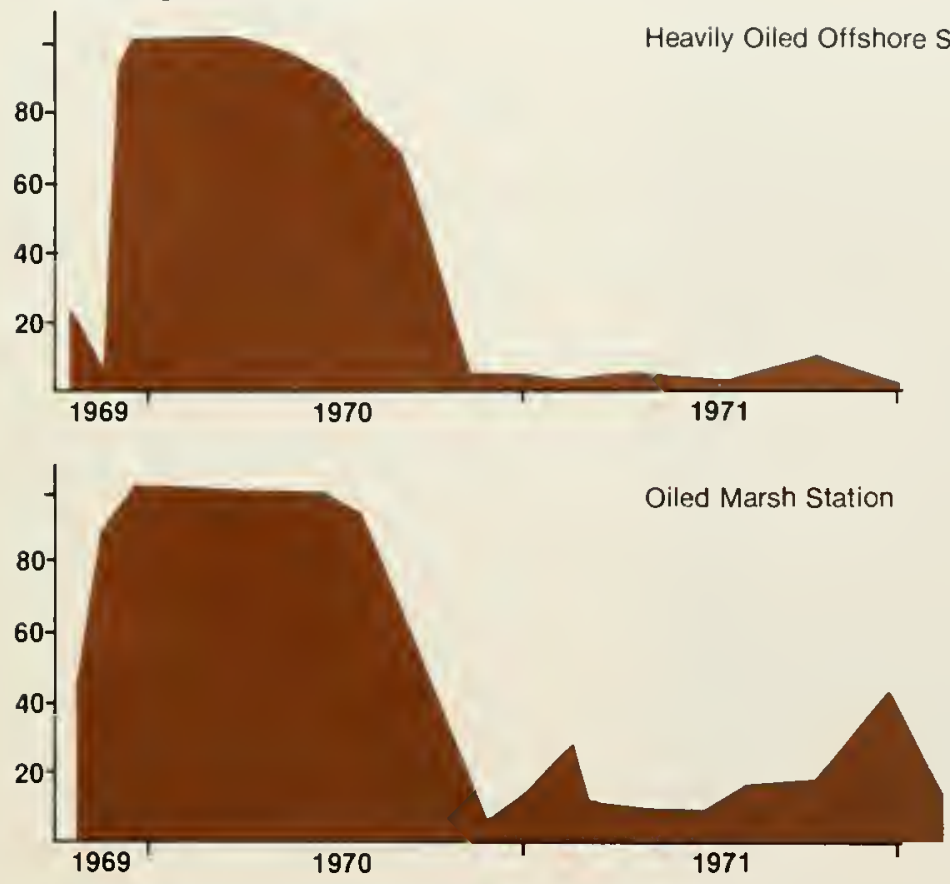

Source: Sanders, H.L., et al., IN PRESS. Anatomy of an Oil Spill: The West Falmouth Study. Draft Submitted to EPA. pp. $85,86,87$.

\section{Nature of Recovering Communities}

Numbers of Species - The heavily oiled station showed a greatly reduced number of species for at least two years after the spill and subsequent studies showed significantly reduced numbers of species for years afterwards. In addition, the number of species was much more variable through time at the oiled stations than at the offshore control station.

Opportunistic Species - In the first year after the spill, the opportunistic worm Capitella capitata exploited the biological vacuum that was caused by the spill. Marine opportunistic "weed" species are similar to weed species found on land, and are characterized ty high rates of reproduction, short life cycles, impressive powers of dispersion, and a general hardiness and adaptability. The marine worm Capitella becomes fully mature in several weeks, is very prolific, and is resistant to many types of pollution, including oil. 

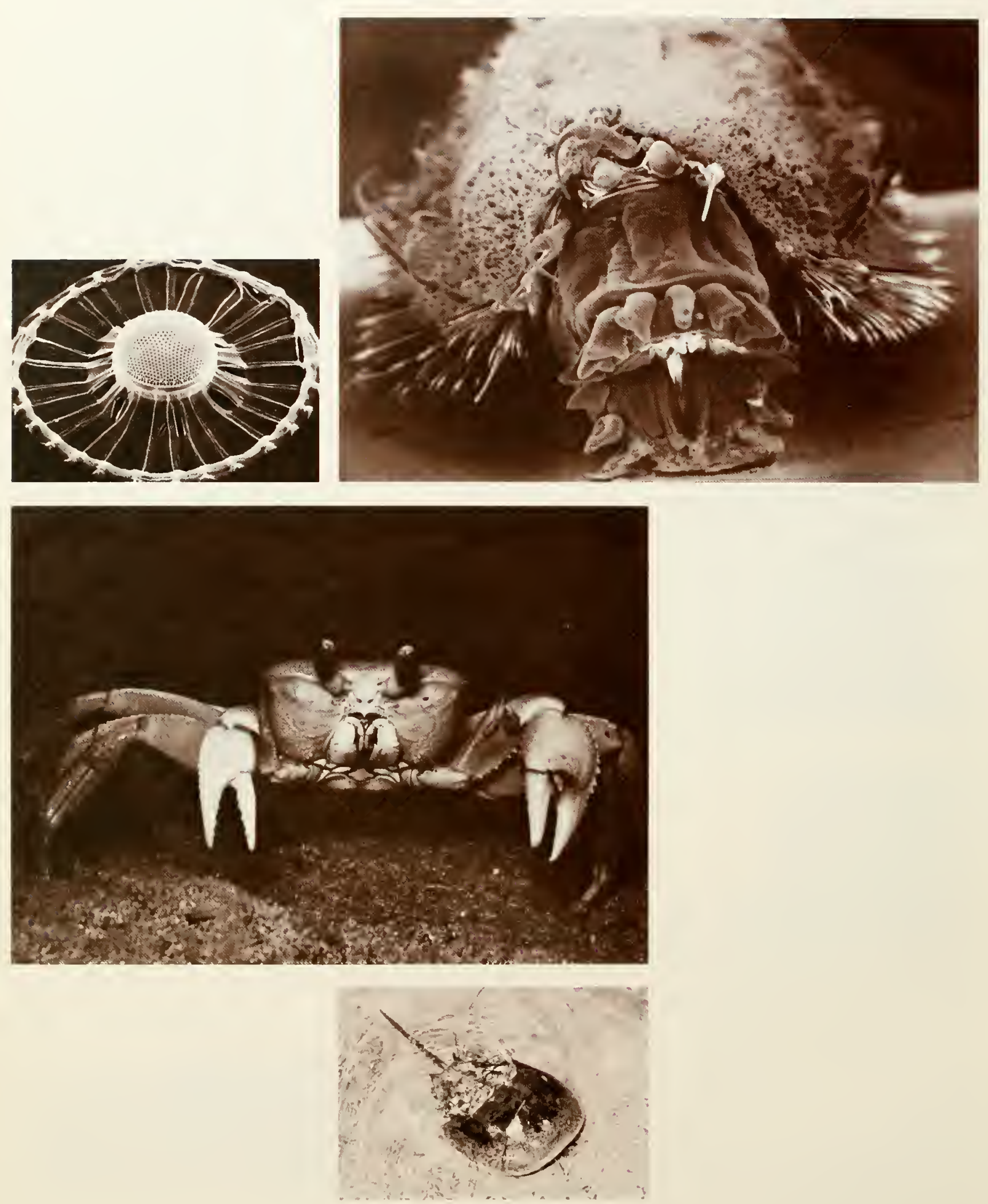


\section{What About Sublethal Effects?}

So far, we have looked at the initial mortality from the spill and the recovery of affected communities. Other studies of specific species have demonstrated significant sublethal effects froin chronic exposure of animal populations to oil. These effects are reflected in the physical defects and abnormal behavior observed in affected animals. Sublethal effects are more subtle than direct mortality and are important to consider because they may occur at very low concentrations of oil and can have serious long term implications in the survival of a species in an affected area.

A study of the Wild Harbor marsh fiddler crab (Uca pugnax) demonstrated the severe chronic effects of the West Falmouth spill - population densities were still reduced seven years after the spill. The fiddler crab is important in salt marsh food webs and in energy flow between the marshes and open waters.
Krebs and Burns concluded that "oil spilled in certain environments may have rather short-term effects on benthic organisms, oil stranded in marshlands contaminates the sediments and becomes incorporated in the tissues of marine organisms affecting the survival and recovery of marine populations for many years. Recovery from even this small spill of fuel oil at West Falmouth is still incomplete after seven years."

These effects were detailed in the study of a single marsh species. Laboratory experiments and studies of other spills have shown that oil pollution also disrupts the functions of whole communities and ecosystems.

These disruptions are less obvious than mass mortality. In a finely balanced ecosystem they are no less dangerous. The West Falmouth study has shown that chronic oil pollution and its insidious long term effects can be caused by a single, small spill.

\section{Sublethal Effects on Fiddler Crabs}

- Caused behavioral problems such as disorientation and loss of a rapid escape response.

- Triggered physical disorders such as increased molting and inappropriate display of mating colors.

- Contributed to heavy winter mortality through abnormally shallow burrows.

- Reduced the ratio of females to males.

- Prevented normal settlement of juveniles, thereby disrupting the age class distribution.

\section{Sublethal Effects on Ecosystems}

- Disruption of normal behavior feeding, breeding, locomotion

- Interference with thermoregulation - control of body temperature in birds and mammals

- Abnormal biological processes

- Reproductive rates

- Growth rates

- Competitive balance

- Predator-prey interactions

- Population age structure

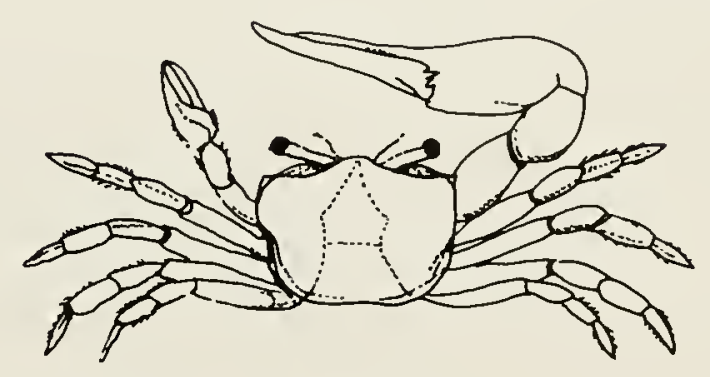

Fiddler Crab (Uca pugnax) 


\section{Implications of West Falmouth}

\footnotetext{
"A very important question is why, in this case, can effects be shown after such an extended time period. Does the West Falmouth oil spill represent a special case?" A. D. Michael, C. R. Van Raalte, and L. S. Brown, Marine Biological Laboratory, Woods Hole, Massachusetts.
} 


\section{What Did the West Falmouth Studies Show?}

Taken together, the several research efforts directed at the West Falmouth spill provide irrefutable evidence of the effects of this particular spill. Contamination with oil from the barge Florida was demonstrated by chemical analysis and correlated with ecological impacts ranging from mortality to behavioral disturbances.

\section{Effects of the West Falmouth Oil Spill}

- There was severe local mortality of the plants and animals of intertidal marsh and subtidal softbottom communities.

- Impacted communities required years for recovery. Communities in early recovery phases were characterized by reduced species numbers, dominance of opportunistic species, and large fluctuations in populations.

- The No. 2 fuel oil was persistent, especially in the sponge-like marsh areas which served as a source of recontamination by continuously oozing oil. Years after the spill, traces of fuel oil were found in plants and animals of oiled areas. The recovery capacity of the communities was compromised by the persistent and shifting fuel oil.

- Sublethal effects of chronic oil pollution were apparent for at least seven years after the spill.

\section{Pollution Effects on Marsh Ecosystems}

- The dominance of opportunistic species in recovering communities reduces the diversity of food items offered to bottom feeders, thereby interfering with the normal transfer of energy from lower to higher levels of the food web, including man.

- Loss of marsh grass reduces the effectiveness of a marsh as a nursery area for marine organisms, a runoff water purification system, and a land stabilization mechanism.

\section{Are These Effects Significant?}

Pollution impacts are often considered in terms of financial loss. This type of loss certainly occurred at West Falmouth where the local shellfishing and tourist industries experienced immediate and obvious damage. But we must also recognize the importance of a healthy biosphere to man. Recreation and aesthetic enjoyment are aspects of a healthy environment that are certainly important. Beyond aesthetics are the basic life support services that nature provides for humans and all other organisms. At the most fundamental level, these include the provision of clean air and water, and the transformation of solar energy into usable food items. These natural life support services are provided by complex interactions between different types of organisms and their environments: the functioning ecosystem. Control mechanisms have evolved to form systems that are resilient by virtue of their complexity. Scientific studies clearly show that pollution and the altering of habitats challenge the resiliency of natural ecosystems and undermine the functioning of nature as a life support system.

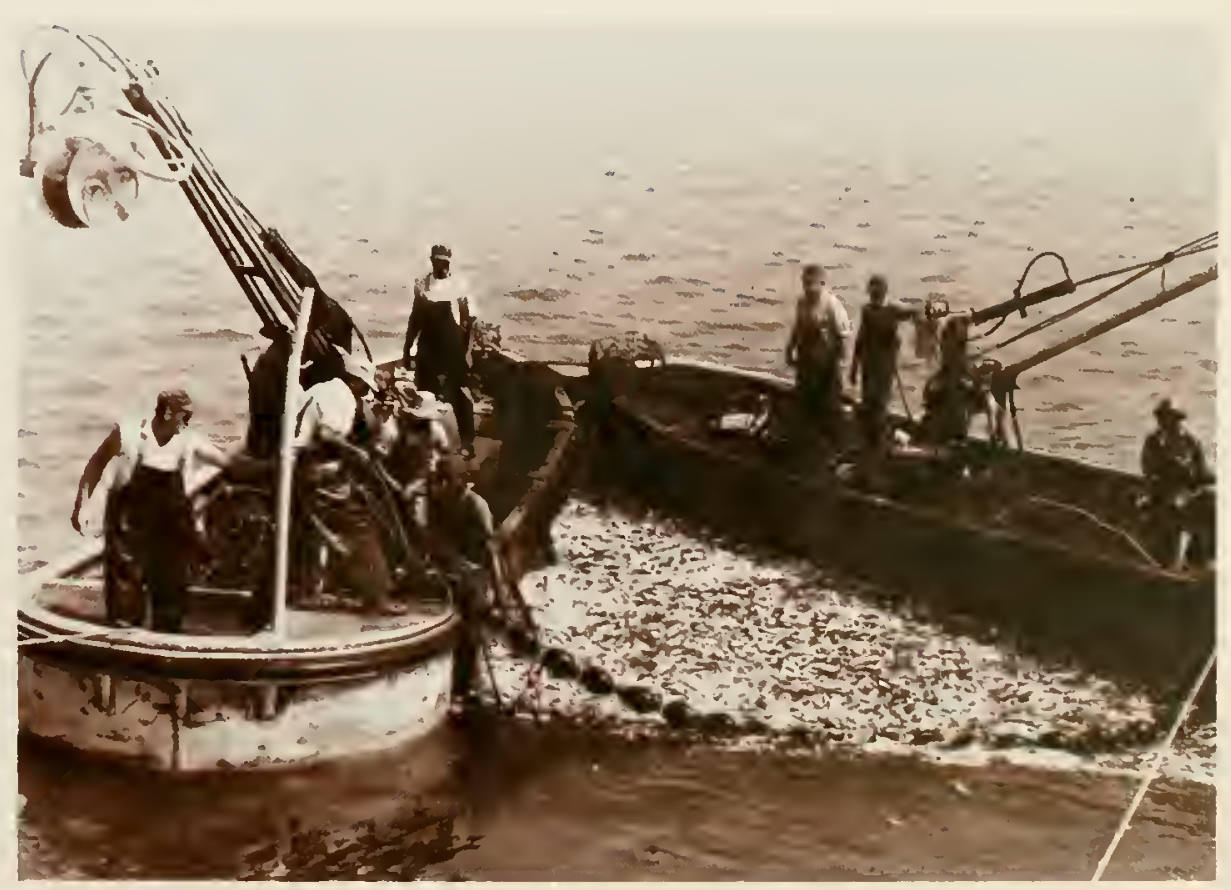




\section{What About Other Spills?}

No other oil spill has been as thoroughly studied as was West Falmouth. Indications are that every spill does not cause the long-term damage observed at West Falmouth, and it must be remembered that this spill affected a relatively small area. Offshore regions and rocky habitats are thought to be less sensitive than the marsh and shallow tidal areas. Other factors that are important in determining the severity of oil spill effects are: the size of the spill, the toxicity of the spilled oil, the time of year, and the sensitivity of the organisms exposed to oil. In some cases, it is clear that oil spills can cause serious long-term damage. Ecosystems may also be exposed to additional oil spills before they have completely recovered from previous pollution incidents. For example, the oil spilled by the Amoco Cadiz off the Brittany Coast in 1978 impacted some of the same areas as the Torrey Canyon spill of 1967. Small local spills occur with great frequency along all of our coastlines. Because complete recovery of communities can require up to ten years, or perhaps longer, the possibility of permanently changing the biological systems of our coasts through chronic exposure to spilled oil is a very real one.
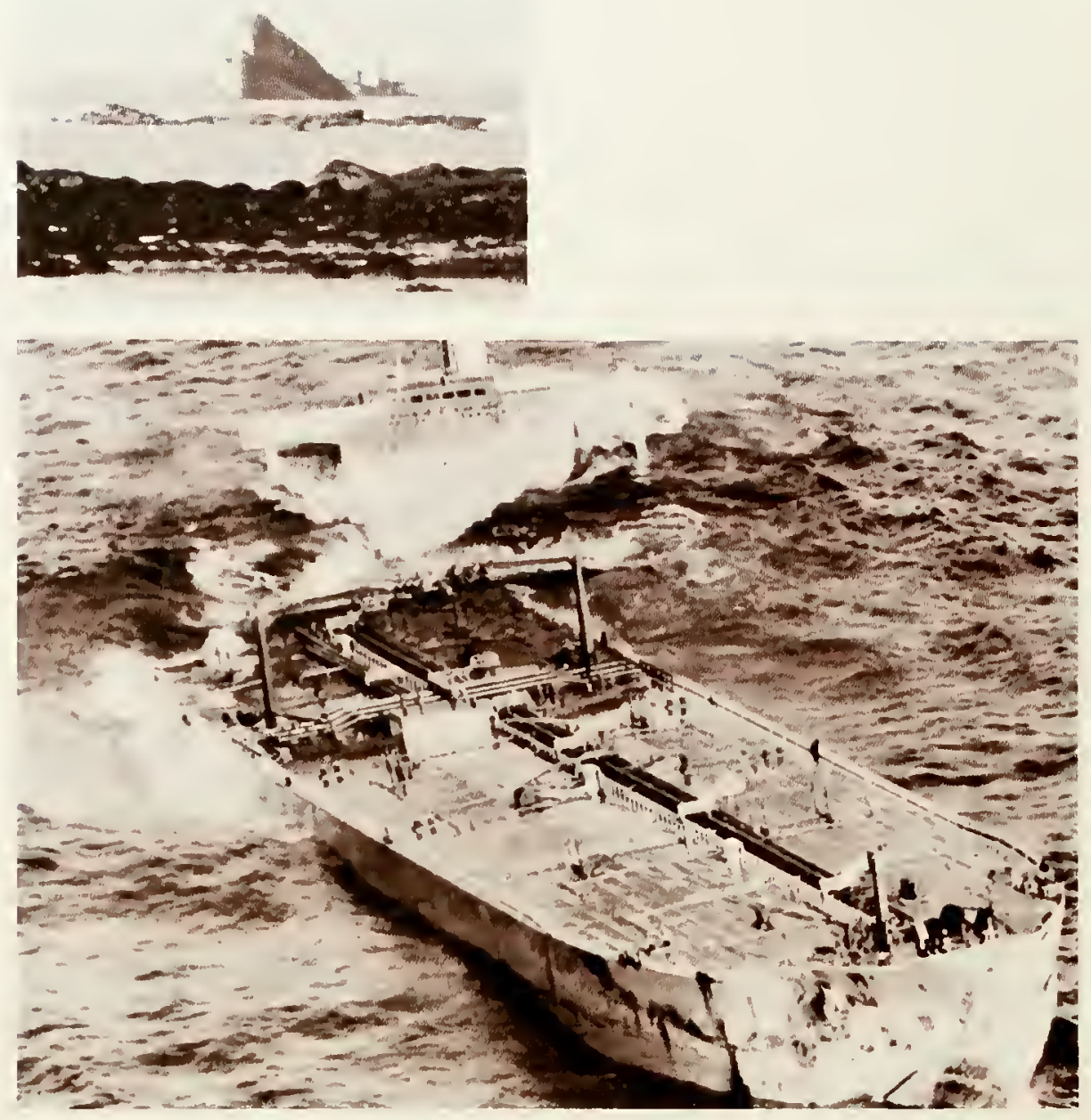

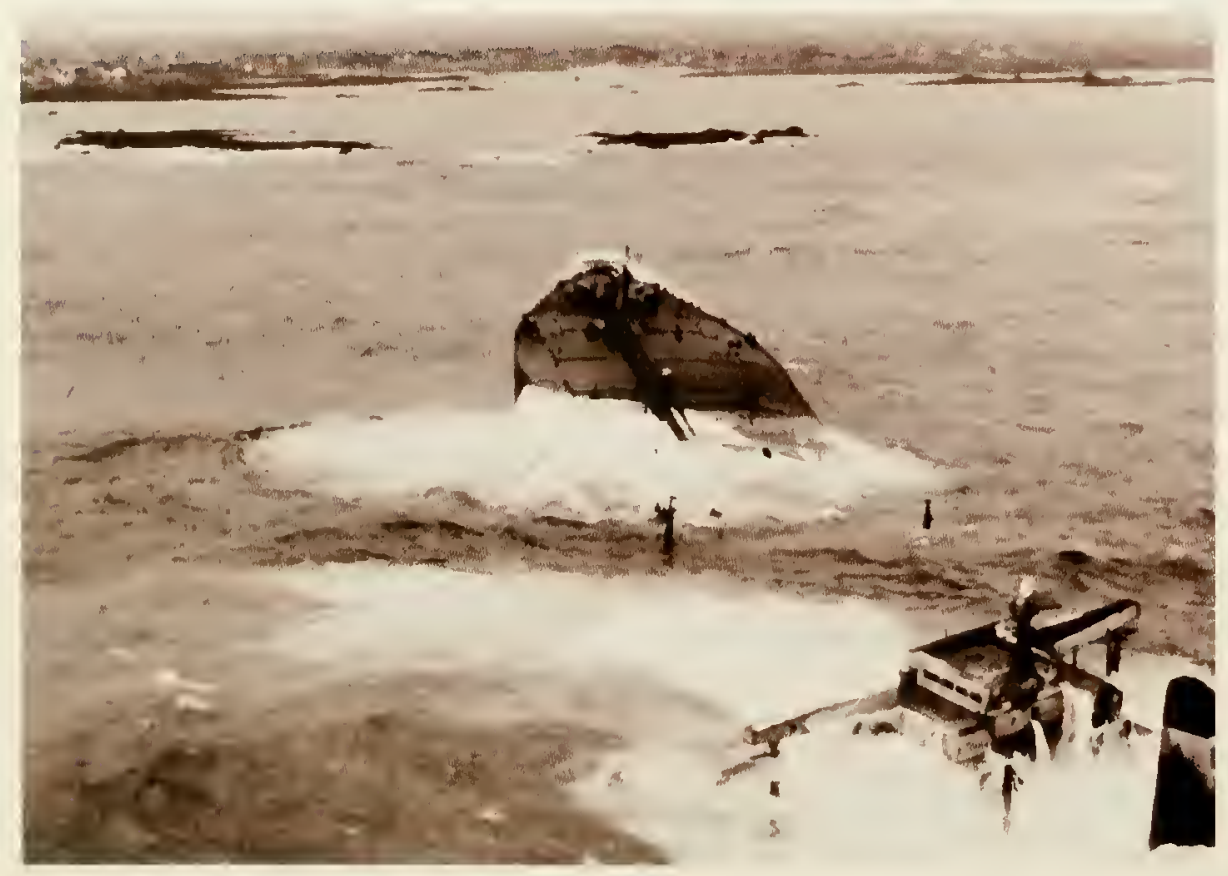




\section{Is More Research Needed?}

Yes. The West Falmouth researchers have shown the value of rigorous, multi-disciplinary research. If other spills had been more thoroughly investigated, would more serious impacts have been discovered? Further research can answer this question. Workers in the field of oil pollution have identified the following research needs including long-term effects of spills, field studies of ecosystems where chronic contamination exists, and combined field and laboratory studies addressing the significance of sublethal effects. The West Falmouth spill has emphasized the importance of the persistence of oil and the significance of sublethal effects.

Such research is costly, especially offshore oceanographic research which involves the use of ships and complicated hardware in the field, and long hours of laboratory effort for sample processing. Analysis of data is also costly because of the need for computers in state-of-the-art analyses. But this research can answer important questions about the effects of pollution.

\section{What Is the Federal Government Doing?}

Federal agencies are conducting research to learn more about spilled oil and its ecological effects. The principal research programs are administered by the Department of the Interior, Bureau of Land Management; the Department of Commerce, National Oceanic and Atmospheric Administration; National Science Foundation; and the Environmental Protection Agency. Research is aimed at developing spill detection and cleanup procedures, investigating ecological effects, documenting baseline environmental conditions and projecting the likely impacts of offshore petroleum resource development and oil transport.
The federal government is also concerned with emergency response to oil spills. The National Response Team (NRT) is a multi-agency organization that is responsible for oil spill contingency planning at the national level. The primary agencies represented on the NRT are the Department of Transportation (U.S. Coast Guard), Department of Commerce (National Oceanic and Atmospheric Administration), Environmental Protection Agency, Department of the Interior, and Department of Defense. The NRT, through the provisions of the National Contingency Plan, ensures that appropriate spill cleanup operations are undertaken. The Environmental Protection Agency supplies quick response technical support on national and regional levels to provide the scientific expertise needed to make decisions about cleanup operations, to assess the ecological damage resulting from a particular spill, and to coordinate research efforts in the spill area. Through these and related programs, the federal government is attempting to reduce the frequency of oil spills, to effectively mitigate the impacts of spills when they occur, and to learn more about the effects of oil pollution.

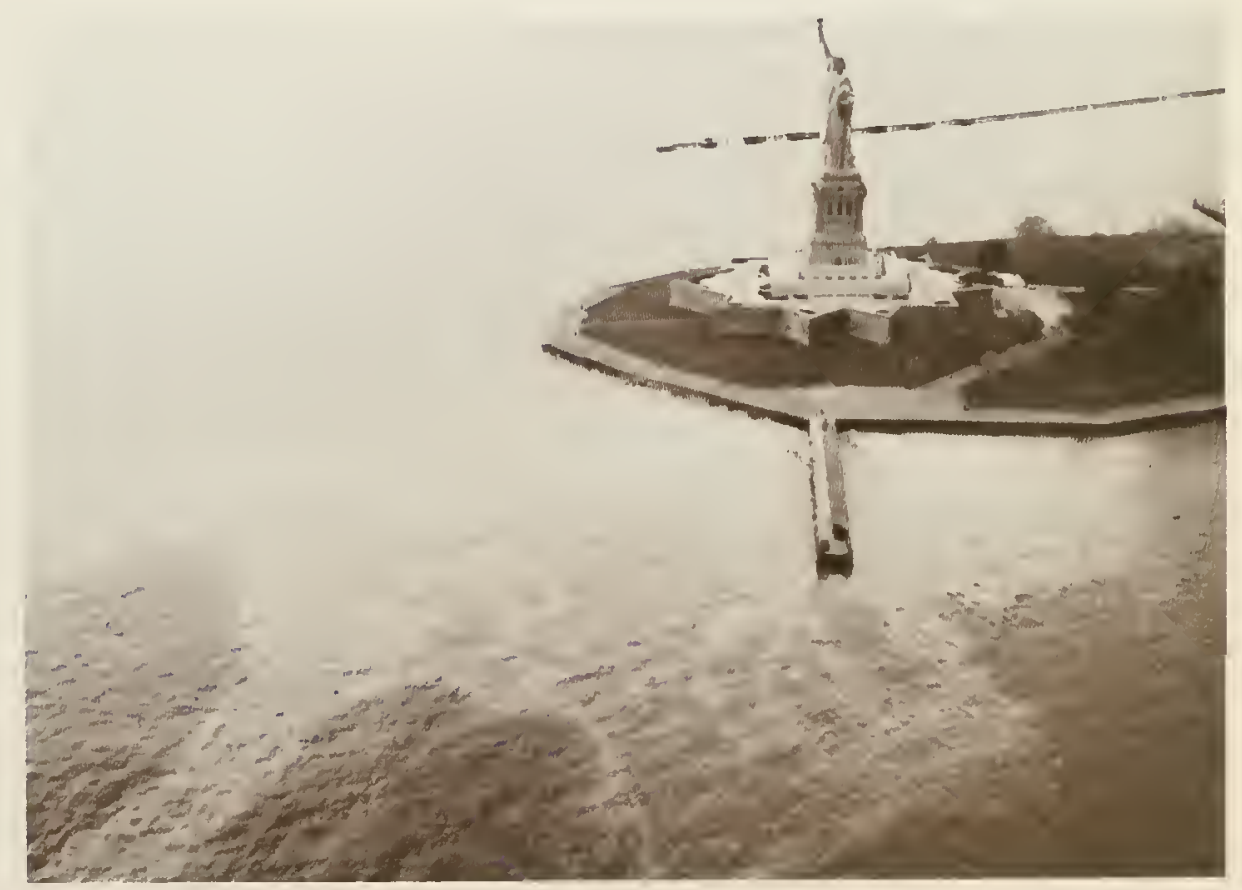




\section{In Overview . . .}

Oil is at once a necessary component of our energy budget and a demonstrated threat to the marine environment. Judiciously conducted research will further describe the environmental price that society is paying for oil pollution. It is the responsibility of citizens and decision makers to plan a reasonable course of petroleum resource development considering both energy requirements and the environmental consequences of energy use.

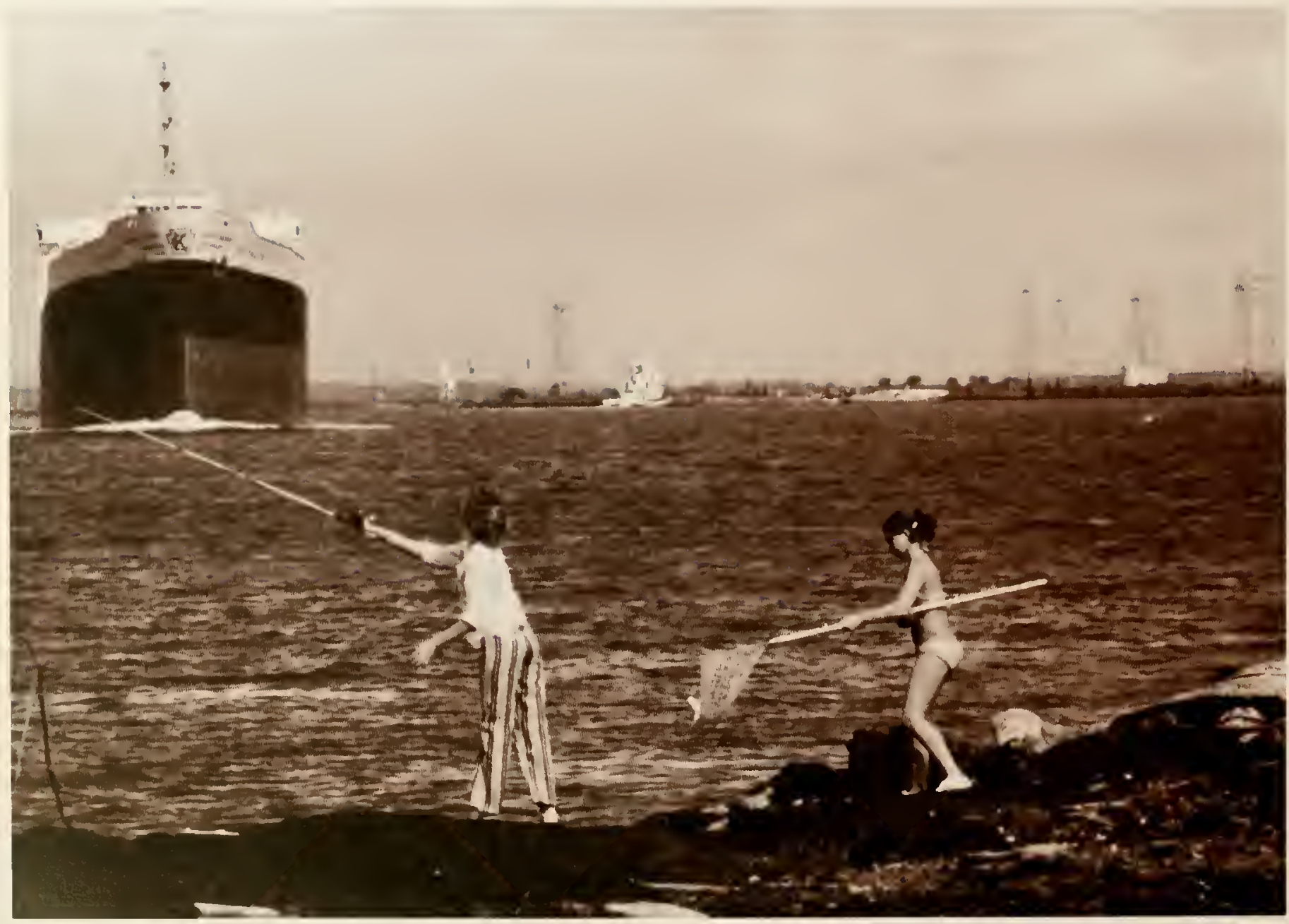




\section{For Additional Information}

Local Oil Spill. G.R. Hampson and H.L. Sanders. Oceanus, Vol. 25, pp. 8-11 (1969).

Description of the immediate effects of the West Falmouth spill.

An Ocean of Oil. M. Blumer, H.L. Sanders, J.R. Grassle, and G.R. Hampson. Environment, Vol. 13, No. 2, pp. 2-12 (1971).

An informative, easily understood presentation of the short-term impacts of the West Falmouth spill.

A Reporter at Large - A Small Spill. W. Wertenbaker. The New Yorker, Nov. 26, 1973.

A personal look at the West

Falmouth spill.

The West Falmouth Saga. H.L. Sanders. New Engineer, pp. 32-36 (1974).

The rebuttal of a respected scientist to misinterpretation of his own research.

Aftermath of an Oil Spill: A Black Seven years. Science, Vol. 112, No. 6, p. 84 (1977).

$A$ one page summary of a seven-year study on the effects of the West Falmouth spill as felt by the fiddler crab.

Effects of Oil on Marine Ecosystems: A Review for Administrators and Policy Makers. D.R. Evans and S.D. Rice. Fishery Bulletin: Vol. 72, No. 3, pp. 625-638 (1974).

An easily understood review of ecological effects of oil spills.

Oil Spills: Issues and Actions. T.L. Leitzell. Marine Technology Society Journal, Vol. 11, No. 1, pp. 26-29 (1977).

A review of technical and legal aspects of oil spills.

The Disaster That Didn't. D. Dedera. EXXON USA, Vol. XVI, No. 3, pp. 11-15 (1977).

The oil industry looks at oil spills.

Being Prepared for Future Argo Merchants. J.H. Milgram.

Technology Review, Vol. 79, No. 8, pp. 14-27 (1977).

A popular analysis of the Argo

Merchant incident.
National Oil and Hazardous Substances Pollution Contingency Plan. Federal Register, Vol. 40, No. 28, pp. 6281-6302 (1975).

A discussion of federal response to oil spills, including agency responsibilities and contingency operations.

Oil Spills - EPA Research Summary. Mark Schaefer, ed. EPA-600/ 8-79-007. February 1979.

A description of EPA research programs dealing with oil spills.

\section{Photo Credits:}

Cover Carl T. Herrman/MITRE Corporation

2 Benjamin S. Harrison, Buzzards Bay, MA

3 Carl T. Herrman/MITRE Corporation

4 EPA Documerica

7 William Lang, US EPA Environmental Research Lab, Narragansett, RI

8 Courtesy Falmouth Enterprise

10 William Lang, US EPA Environmental Research Lab, Narragansett, RI

12 Carl T. Herrman/MITRE Corporation

15 (top) G.R. Hampson, Woods Hole Oceanographic Institute

15 (bottom) William Lang, US EPA Environmental Research Lab, Narragansett, RI

16 US EPA National Marine Water Quality Lab, Narragansett, RI

17 Paul Dix, US EPA Environmental Research Lab, Narragansett, RI

18 William Lang, US EPA Environmental Research Lab, Narragansett, RI

22 (top left, Planktoniella sol [diatom]) Dr. Paul Hargraves, Graduate School of Oceanography, University of Rhode Island

22 (top right, Scaleworm) Dr. John Sieburth, Graduate School of Oceanography, University of Rhode Island

22 (middle, Crab) William Lang, US EPA Environmental Research Lab, Narragansett, RI

22 (bottom, Horseshoe Crab) Carl T. Herrman/MITRE Corporation

24 EPA Documerica

25 NOAA

26 (top) US EPA Environmental Research Lab, Narragansett, RI

26 (middle) UPI

26 (bottom) NOAA

27 EPA Documerica

28 EPA Documerica

\section{Technical References}

Blumer, M. and J. Sass. 1972. Oil Pollution Per sistence and Degradation of Spilled Fuel Oil. Science 176: 1120-1122.

Farrington, J.W. 1977. Oil Pollution in the Coastal Environment. In Estuarine Pollution Control and Assessment: 385-400. EPA 440/1-77-007.

Gilfillan, E.S. 1975. "Decrease of Net Carbon Flux in Two Species of Mussels Caused by Extracts of Crude Oil." Marine Biology 29: 53-58. Grassle, J.R. 1972. "Species Diversity, Genetic Variability and Environmental Uncertainty." In Fitth European Marine Biological Symposium: 19-26.

Grassle, J.F. and J.P. Grassle. 1974. "Opportunistic Life Histories and Genetic Systems in Marine Benthic Polychaetes." Journal of Marine Research 32 (2): 253-284.

Krebs, C.T. and K.A. Burns. 1977. 'Long-Term Effects of an Oil Spill on Populations of the Salt-Marsh Crab Uca pugnax." Science 197: 484-487.

Maiero, David J., R.J. Castle, O.L. Crain. 1978. Protection, Cleanup and Restoration of Salt Marshes Endangered by Oil Spills - A Procedural Manual. EPA 600/7-78-220.

Michael, A.D. 1976. "The Effects of Petroleum Hydrocarbons on Marine Populations and Communities." In Proceedings from Oil Symposium in Seattle, Washington: 129-137.

Michael, A.D., C.R. Van Raalte and L.S. Brown. 1975. "Long-Term Effects of an Oil Spill at West Falmouth, Massachusetts." In Proceedings of a Conference on Prevention and Control of Oil Pollution: 573-582. API.

Moore, S.F. and R.L. Dwyer. 1974. "Effects of Oil on Marine Organisms: A Critical Assessment of Published Data." Water Research 8: 819-827. Odum, W.E. 1970. "Insidious Alteration of the Estaurine Environment." Transactions of the American Fisheries Society 99 (4): 836-847. Sanders, H.L. IN PRESS. "Florida Oil Spill Impact on the Buzzards Bay Benthic Fauna: West Falmouth." Draft of a paper presented at Oil/ Environment, 1977. Halifax, Nova Scotia.

Sanders, H.L., J.F. Grassle, G.R. Hampson, L. Morse, and S. Garner-Price. IN PRESS.

"Anatomy of an Oil Spill: The West Falmouth Study." Draft submitted to EPA under Grant No. R801001-024.

Straughan, D. 1972. "Factors Causing Environmental Changes After an Oil Spill." Journal of Petroleum Technology 24: 250-254.

Westman, W.E. 1977. "How Much Are Nature's Services Worth?" Science 197: 960-964. 
United States

Environmental Protection

Agency
Pnstage and

Fees Paind

Environmental

Pretectien

Agency

EPA. 335

Official Business

Penaity for Private Use

$\$ 300$

\section{준}

Third Class Bulk Aate 